\title{
Building Warships and Nurturing Technical Talent at the Foochow Navy Yard during the Self- Strengthening Movement
}

\author{
LI Mingyang 李明洋1
}

(Institute for the History of Natural Sciences, Chinese Academy of Sciences, Beijing 100190, China)

\begin{abstract}
In 1866, after the Opium Wars, the Chinese official Zuo Zongtang established the Foochow Navy Yard, which aimed to facilitate the independent construction of modern warships. French advisers, engineers, teachers, and craftsmen were hired, and a series of French schools for naval construction, drawing, and apprenticeship were set up. Previous studies have nearly exhausted the historical material on the Foochow Navy Yard, but few of them give an exact evaluation on its shipbuilding and educational levels. This paper traces the French sources on the shipbuilding technology and educational system at the Foochow Navy Yard and conducts a comparative study. With the guidance and assistance of foreigners, the Foochow Navy Yard gained the ability to assemble ships and imitate engines, while it remained necessary to import design drawings and structural components. The most outstanding students that the navy yard nurtured may have reached the level of École Polytechnique graduates, but the quality of students was hard to maintain. The backwardness of its conceptualization and the lack of financial and political support also contributed to its decline.
\end{abstract}

Keywords: Foochow Navy Yard, Self-Strengthening Movement, technology transfer, technical education

摘 要: 两次鸦片战争后, 左宗棠于 1866 年创建福州船政, 旨在掌握独立建造现代舰
船的能力。船政雇佣了法国顾问、工程师、教师和工匠, 并建立了一系列法文学堂, 进
行造船、绘图及学徒教育。前人研究已经几乎探清了福州船政的历史细节, 但很少对船
政的造船和教育水平给出准确的评估。本文追溯船政造船技术和教育制度的法国源头并
进行比较研究, 认为在洋人的指导和帮助下, 福州船政已经具备组装舰船和仿制蒸汽机
的能力, 而设计图纸和重要的结构件仍需进口。船政所培养出最优秀的学生或许可以达
到法国综合理工学校毕业生的水平, 但优质生源难以为续。观念的落后以及资金和政策

Received: April 3, 2020. Revised: November 16, 2020.

This paper was translated into English by Yu Yueyuan 俞月圆 and copyedited by Charlie Zaharoff.

1 Research interest: History of technology and engineering. Email: limingyang@ihns.ac.cn 
的支持不足, 也是导致船政衰败的因素。

关键词：福州船政，自强运动，技术转移，技术教育

Tn the nineteenth century, relying on their military, economic, scientific, and Itechnological advantages, industrialized Western countries expedited their expansion of control over other parts of the world, which in turn drove the transnational and transcultural transfer of technology and science and caused social changes and responses of various magnitudes, military conflicts, and partial industrialization in non-industrialized countries. After the Opium Wars, under the pressure of being invaded by Britain and France, among others, Imperial China was forced to open trading ports to the West, and in the early 1860s started its SelfStrengthening Movement (Ziqiang Yundong 自強運動) or “Westernization” (Yangwu Yundong 洋務運動), which took “learning the superior technology of the barbarians" (shi yi zhi changji 師夷之長技) as its strategy (Zhang, Tian, and Zhang 2017, 52-57). During the Self-Strengthening Movement, more than twenty military enterprises were set up by the Qing government, one of the most important among them being the Foochow Navy Yard. $^{2}$ Established in 1866, the Foochow Navy Yard lasted for almost half a century (1866-1907) and consisted of a shipyard and a school.

The Foochow Navy Yard has attracted much attention from scholars who specialize in the history of nineteenth-century China or in the relationship between China and the West. In the 1930s, Chinese scholars including Wang Xinzhong 王信忠 and Gideon Chen 陳其田 held that the Foochow Navy Yard failed to produce results that corresponded to the money and effort that had been invested in the enterprise (Wang 1932, 1-57; Chen 1938, 14-48, 79-86). During the 1980s and the 1990s, following the line of technology transfer, Steven Leibo studied the role that Prosper Marie Giquel, who was the technical advisor of the Foochow Navy Yard, played in the early development of the Foochow Navy Yard. David Pong did his research on the Confucianism of Shen Baozhen 沈葆楨 (Shen Pao-chen), general director of the shipyard, and its influence upon Shen's efforts during the Westernization. Marianne Bastid-Bruguière did an early study on students who were sent to France to study by the Foochow Navy Yard. Chinese scholars Lin Qingyuan 林庆元, Lin Chongyong 林崇墉, and some others carefully collected and collated the historical materials written in Chinese. The studies enumerated above mainly focus on the personnel and financial situation of the Foochow Navy Yard, with an emphasis on the non-technological reasons behind the

2 Academia has not reached a consensus on the English translation of "Fuzhou Chuanzheng" (福 州船政). Prosper Giquel's report, written in French, called it "L'Arsenal de Fou-Tchéou." In previous studies, Knight Biggerstaff used "Foochow Navy Yard School" to refer to the school of Fuzhou Chuanzheng. Steven Leibo used "Fuzhou Dockyard," while David Pong used "Foochow Navy Yard." In fact, the connotation of the Chinese term "chuanzheng" (船政) is richer than the way in which these scholars used it; it can represent all the matters related to shipbuilding. 
gradual decline of the enterprise. In the last two decades, naval history scholars including Yau-Woon Ma 馬幼垣 and Chen Yue 陈悦 have engaged in a technological investigation of the French vessels that the Foochow-built warships imitated. Although research on the Foochow Navy Yard has yielded fruitful results, some key issues of the technology transfer have not yet been fully understood. This paper concentrates on the manufacturing technology and engineering education between 1866 and 1890 in the Foochow Navy Yard, investigating two main questions: (1) Where did the Navy Yard and its shipbuilding technology stand in terms of the worldwide shipbuilding industry at that time? (2) How successful were the engineers and workers nurtured by the Navy Yard in terms of the technology that they attempted to master?

\section{Choosing French technology}

Why did the Foochow Navy Yard choose to emulate French shipbuilding technology? In October 1860, the British-French forces entered Beijing and forced the Qing government to sign The Convention of Peking (Beijing Tiaoyue 北京條約). In December 1860, Zeng Guofan 曾國藩 (Tseng Kuo-fan), governor-general of Liangjiang (or Liangkiang, including today's Jiangsu, Anhui, and Jiangxi Provinces) 兩江總督, suggested to the court that "in the future, we should learn the wisdom of the barbarians to cast cannons and build ships, from which long-term benefits can be expected" (Zeng [1860] 1985, 370). ${ }^{3}$ His proposal won the support of Yixin, Prince Gong 恭親王奕诉. Later on, officials including Zeng Guofan, Li Hongzhang 李鴻章 (Li Hung-chang), and Zuo Zongtang 左宗棠 (Tso Tsung-t'ang) all attempted to adopt European weapons and technology in their prefectures. Meanwhile, Britain, France, and some other countries displayed a willingness to take part in China's Westernization and other internal affairs (including helping the Qing government to suppress uprisings) so as to gain greater benefits and expand their influence upon the "East Asian order."

China's choice to work with France in establishing a shipbuilding enterprise is directly related to the communication between the French and the navy yard's principal founder, Zuo Zongtang. In the early 1860s, Horatio Nelson Lay, who served as inspector general of the Chinese Imperial Maritime Customs Service, was commissioned by the Qing government to set up a "Sino-British Joint Fleet." However, the fleet, which arrived in China in 1863, was finally dissolved due to the dispute over its control. While the controversy surrounding the "Sino-British Joint Fleet" was still ongoing, the French founded a small dockyard at Ningbo and built several gunboats,

3 “將來師夷智以造炮製船, 尤可期永遠之利。” The memorial that contains this idea was actually ghostwritten by Zuo Zongtang 左宗棠, but this should not undermine the argument here, as the quote reflects the shared opinion of Zeng and Zuo. See Sun (1995, 360-361). 
which was viewed by the British as an attempt to replace the "Sino-British Joint Fleet." 4 In 1864, Jean-Louis-Charles Jaurès, commander of the China and Japan Seas Naval Division, expressed his hope that the Chinese could take over the dockyard in Ningbo. This was passed on to Zuo Zongtang, governor-general of Fujian and Zhejiang, via Prosper Giquel and Paul-Alexandre Neveue d'Aiguebelle. ${ }^{5}$ Having learned that this dockyard could only produce hulls, while steam engines and guns would have to be purchased from France, Zuo declined Jaurès's offer. ${ }^{6}$ During the negotiation, a new proposal that the Chinese found a dockyard and build warships under the guidance of the French was formed.

Previously, in Hangzhou, Zuo had ordered craftsmen to imitate some small boats, yet the boats that they built moved slowly. Having consulted Paul-Alexandre Neveue d'Aiguebelle and Prosper Giquel, Zuo learned that "(the boat) is close to its model in general, except that the steam engine should be purchased from the West. If so, the ship would be able to travel more swiftly." 7 Zuo then invited d'Aiguebelle and Giquel to "help to supervise the shipbuilding, and to introduce the European method into China" (Zuo [1866] 1986, 2852-2853). In January 1865, commissioned by Zuo Zongtang, d'Aiguebelle returned to France to gather information and recruit workers for the shipbuilding project. On February 19, d'Aiguebelle submitted a report on the estimated expenditure to Zuo Zongtang. ${ }^{8}$ In the summer of the same year, Napoleon III received $\mathrm{d}^{\prime}$ Aiguebelle and in writing expressed his support for the plan of building ships for

4 Hong Kong Trade Report, July 11, 1864, cited in W. Sykes to Russell, July 11, 1864, NO. 577, F.O. 17. 418, fol. 180-181, PRO, quoted in Leibo (1982, 150-151).

"The French are manifesting considerable political aggression at Ningpo - they have established a sort of dockyard and machine factory. There, having by some means obtained some steam engines, they are constructing a flotilla of gunboats to take the place of the 'Lay-Osborn' fleet. The matter looks serious. . . the idea of the flotilla being entirely in the hands of the French cannot be entertained without grave misgiving. French officers are so quick to take offence-so quick to obtain satisfaction-so imperious, so impractical, and so totally uncommercial that they are viewed by the Chinese with great dread and by foreigners with apprehension. . . The object of the French in establishing flotilla would seem to be, not the pacification of the country but domination."

5 Prosper Giquel (1835-1886) was an officer in the French Navy. He served at the Customs Office at Ningbo in 1861 and participated in setting up the Sino-French Ever Triumphant Army 常捷軍, helping Zuo Zongtang, who was then the provincial governor of Zhejiang, to suppress the Taiping Rebellion. Paul-Alexandre Neveue d'Aiguebelle (1831-1875) was a French naval officer as well. In 1863, he became the leader of the Ever Triumphant Army. He was appointed regional commander of Zhejiang by the Qing government and was conferred the rank of provincial military commander. While working together to suppress the Taiping Rebellion, Giquel and $\mathrm{d}^{\prime}$ Aiguebelle were in close contact with Zuo Zongtang, laying the foundation for their subsequent cooperation.

6 Giquel Journal, June 15, 1864, quoted in Leibo $(1982,151)$.

7 “大致不差, 惟輪機須從西洋購䚇, 乃鉌捷便。”

8 D’Aiguebelle to Zédé, February 15, 1869, CCC Ning-Po, Fou-tcheou, vol. 1, fol. 205-206, AE, quoted in Leibo (1982, 157-158). 
China. ${ }^{9}$ On June 25, 1866, Zuo submitted a memorial to the throne, pleading for it to "purchase machinery, recruit foreign craftsmen, and set up an institution to attempt to build ships." 10 In the memorial, Zuo elaborated his plan of shipbuilding and emphasized its significance, pointing out that "if we want to gain benefit from the sea while preventing the danger that comes from there, it is a must to strengthen our navy. If we hope to strengthen our navy, then it is a must to set up an institution to supervise shipbuilding" (Zuo [1866] 1986, 2843-2854).11 On July 14, an imperial edict was issued; Zuo's application was approved. In autumn, Giquel and d'Aiguebelle successively signed a five-year contract ${ }^{12}$ with Zuo Zongtang. The five-year program, which aimed to build ships and nurture talent, thus came into effect.

Zuo Zongtang signed altogether four contractual documents with Giquel and d'Aiguebelle, namely “General descriptions" (Baoyue 保約), “Agreements” (Tiaoyi 條 議, eighteen entries in total), “Budget” (Qingzhe 清折), and “Sample contract" (Hetong guiyue 合同規約, fourteen entries in total). According to these four documents, Giquel and d'Aiguebelle were obligated to hire foreigners to help China "build vessels and purchase products of foreign iron works and ship yards, as well as all the raw materials that are needed."13 At the same time, they should set up a school to "train Chinese students and craftsmen so that they can be proficient in all the principles of building ships, and can build ships and tools on their own. The school would also teach English, French, and knowledge related to shipbuilding and how to operate a ship. The students would fully master these areas of knowledge; the Chinese students and craftsmen would then be able to independently supervise shipbuilding and operate ships by themselves."14 If such goals could be achieved within the five-year contract period, Giquel, d'Aiguebelle, and the foreign employees that they recruited would be awarded a large amount of money (Institute of Modern History, Academia Sinica 1957, 31). Perhaps still a little shaken by the "Sino-British Joint Fleet" incident, the contract elaborates on details of the cooperation, including the varieties and quantities of the

9 D'Aiguebelle to Napoleon III, August 29, 1865, Dossier Individual, Paul Neveue d'Aiguebelle, CC 7 1850, SHM, Vincennes, quoted in Leibo $(1982,158)$.

10 “購買機器、募雇洋匠、設局試造輪船。”

11 “欲防海之害而收其利, 非整理水師不可; 欲整理水師, 非設局監造輪船不可。”

12 The original contract period had been three years, but it was found too short and therefore changed to five years. According to the contract, the five years would "start from the day when the iron works commence production" (鐵廠開廠之日始). Towards the end of the seventh year of Emperor Tongzhi's reign (February 1869 in the Julian calendar), factory buildings of the navy yard were finished in succession. Giquel pleaded for the contract's period of performance to start in the first month of the next year in the lunar calendar. The period therefore lasted from the first day of the eighth year of Emperor Tongzhi's reign (February 11, 1869) to the last day of the twelfth year (February 16, 1874). See Shen ([1869] 2006b, 46).

13 “製造輪船, 並採買外國鐵廠船廠傢伙及一切外國物料等件。”

14 “教導中國員匠, 於造船法度, 一切精熟, 均各自能製造, 並能自造傢伙, 並學堂中教習英法 兩國語言文字, 造船算法及一切船主之學, 均各精熟, 俾中國員匠自能監造駕駛。” 
materials to be purchased, the particulars of foreign employees' salary and the purchasing funds, the basic rules and regulations of the navy yard, and so forth, in order to avoid any trouble that might be incurred by ambiguous wording (Institute of Modern History, Academia Sinica 1957, 31-43). Considering that both Zuo Zongtang and his staff had very limited knowledge of the European legal system, it was especially difficult for them to draw up contractual documents that were legally effective. The contract also reflects that, regardless of his unfamiliarity with matters related to shipbuilding, Zuo Zongtang was determined to keep the navy yard under the absolute control of the Chinese.

The construction of the Foochow Navy Yard started on December 23, 1866. Under the guidance of Adrien M. Trasbot, general supervisor, the infrastructure of the navy yard in Mawei 馬尾 was finished within less than two years (Figures 1 and 2). ${ }^{15}$ This Frenchstyle navy yard was divided into the non-production area and the production area, the former consisting of the government office, the school, and the dormitory, while the latter included the metal-working section and the section for carpentry (Giquel 1874, 5-9, 2636). The production area was equipped with machines imported from France, including steam engines, boilers, steam hammers, rolling mills, bellows, forging furnaces, cupolas, and others. The metal-working section included the School and Office of Drawing (Huishi yuan 繪事院) as well as workshops on foundry, metallurgy, iron-rolling, boilers, and final assembly, and produced steam engines, boilers, metal plates, copper for ships' sheathing, and so on. The carpentry section, on the other hand, comprised construction sites as well as workshops on carpentry, sawmills, instruments, small forges, small fittings, models, and joiners, and mainly produced wooden ships, compasses, components made for ships, and wooden patterns for all kinds of metal parts. The construction sites consisted of three shipways and a hauling slipway of the Labat system (cale de hâlage, système Labat). The Labat-style hauling slipway was invented by Henri Jean Théophile Labat (1834-1896), a French naval engineer, and had only been built once before the Foochow Navy Yard, at Chantiers de l'Océan. ${ }^{16}$ One advantage of this kind of new ship slipway was that it could be controlled in sections so as to accommodate various lengths of ships (Institute of Modern History, Academia Sinica 1957, 263-265).

15 Adrien M. Trasbot graduated from the École Polytechnique and was a shipbuilding engineer at the Arsenal de Rochefort in France. He was appointed by Prosper Giquel as the general supervisor of the Foochow Navy Yard.

16 Chantiers de l'Océan was located in Bacalan, north of Bordeaux, and was owned by Jean Lucien Arman (1811-1873). This shipyard had built warships for different countries, including France, Russia, America, and Italy. The first ironclad ever possessed by the Imperial Japanese Navy, Kōtetsu 甲鉄 (later renamed Azuma 東), which would be sent to invade Taiwan in 1874, was also built there in 1863 (under the name Sphinx for the Confederate States Navy) and changed hands several times before the Tokugawa shogunate 徳川幕府 bought it in 1867. The Labat-style hauling slipway in this shipyard started to be built in 1862 and became operational in 1865. It was ninety meters long with a uniform slope of seven centimeters per meter. 


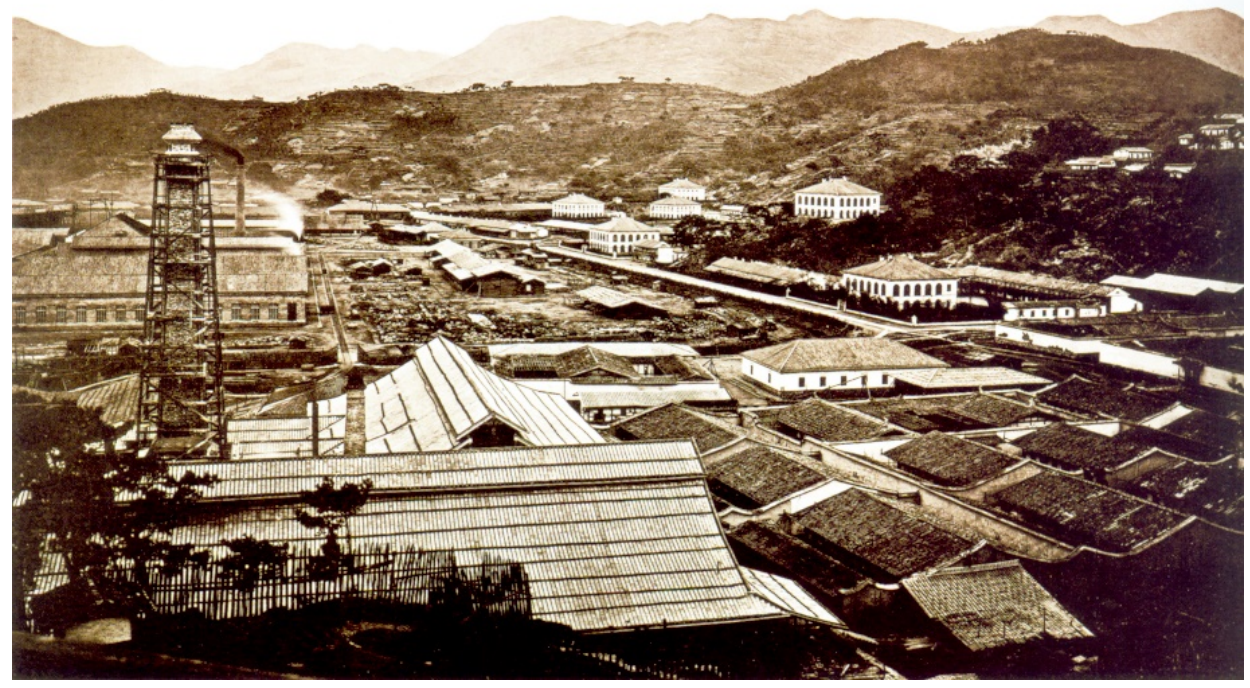

Figure 1: Foochow Navy Yard under construction. The photo was taken by John Thomson, and its original negative is now kept in the Wellcome Library, London. Photo provided by the China Chuanzheng Culture Museum.

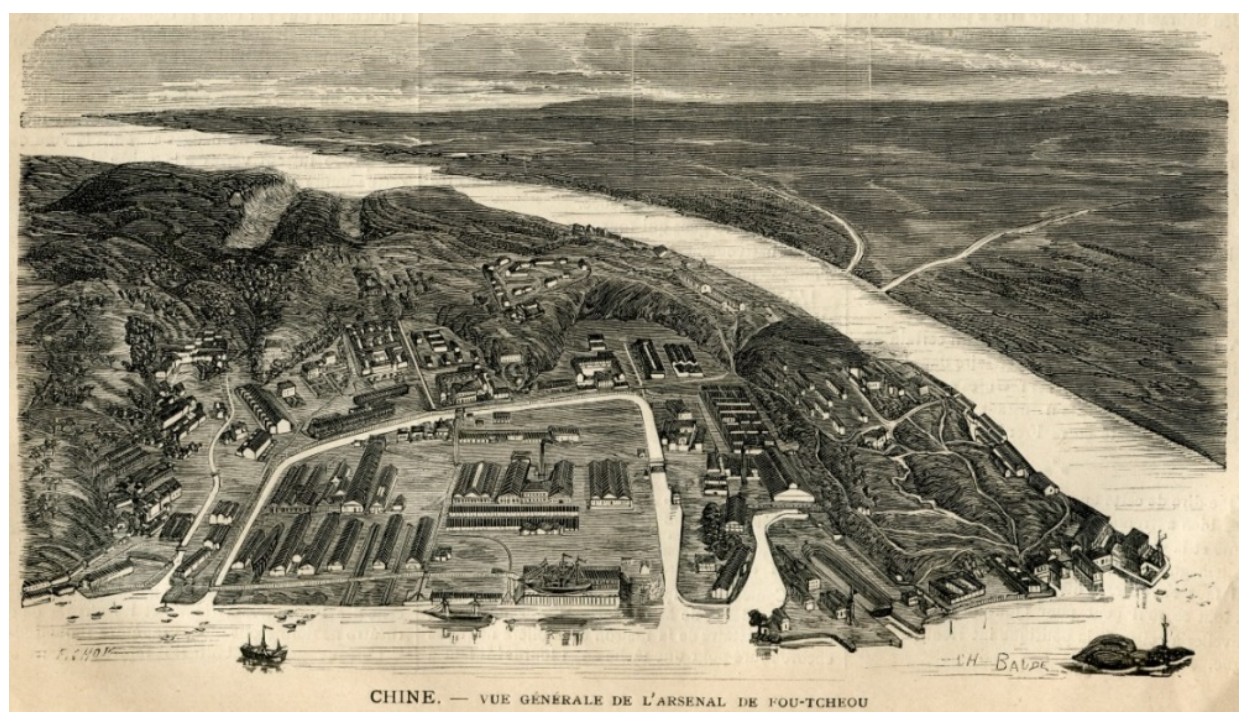

Figure 2: An overall view of the Foochow Navy Yard. ("Chine. - Vue Générale de L'Arsenal de Fou-Tchéou." The illustration is from L'Illustration, journal universel, No. 1629, Vol. LXIII, May 16, 1874, and is scanned from a copy provided by the China Chuanzheng Culture Museum.) 
The four-decade history of the Foochow Navy Yard, starting in 1866 when the construction of the factory building commenced and ending in 1907 when shipbuilding came to a complete stop, can be divided into four phases. From 1866 to 1873, the navy yard built small wooden warships according to the contract that the Qing government signed with Giquel. From 1874 to 1884, the Chinese took over the production, ${ }^{17}$ and the navy yard shifted from building wooden vessels to building iron-ribbed ships with wooden hulls. Between 1885 and 1895, after the Sino-French naval battle in the Majiang River, emphasis was put on building ironclads. From 1896 to 1907, foreign technical experts were again employed to offer guidance on building vessels in the new style. In the first phase, the design of warships basically imitated that of the French ones. Chinese craftsmen, who were familiar with woodwork, were capable of constructing the ship's hull under the instruction of the foreigners. It was unnecessary for the Foochow Navy Yard to cast cannons, as almost all the guns-large and small-that were equipped on the ships were purchased from European arms dealers.

\section{Building wooden warships}

As stipulated in the contract, the French were obligated to help the Foochow Navy Yard build eleven 150-horsepower ${ }^{18}$ warships and five 80 -horsepower warships. As for the engines, foreign products were to be imported and used at first, while later the navy yard was expected to build them on its own. Not long after the navy yard had been established, Giquel and d'Aiguebelle purchased two 150-horsepower double-cylinder vertical engines and two 80-horsepower engines, together with their respective matching boilers. The first two warships built by the navy yard completely followed the design drawings of French warships; the most important equipment, including steam engines on the ship and the matching boilers as well as some metal parts, was purchased from France. The first ship built by the navy yard was Wannian Qing (Wan-nien Ch'ing 萬年清), whose construction began in January 1868, and which later launched on June 10, 1869. It was a three-mast, single-chimney sloop with a wooden frame and a wooden hull. The ship was 76.16 meters long and 8.9 meters wide at its widest point, and sailed at a speed of 8 knots. It was the first steam-powered warship with a displacement of over 1000 tons (1450 tons)

17 Giquel started to assess each of the workshops as early as the summer of 1873 . Meanwhile, the Chinese craftsmen and employees that he selected gradually took over the production. On November 18, 1873, Giquel finished his report on the status quo of the navy yard and submitted it to Shen Baozhen. On December 7, 1873, Shen Baozhen submitted a memorial to the throne, introducing achievements of the five-year program and asking for rewards for Giquel and his colleagues. Thus, it can be concluded that the Chinese had basically taken over the ship yard by the end of 1873 or the beginning of 1874 .

18 The 150-horsepower steam engine used by the Foochow Navy Yard had a nominal horsepower (nhp) of 150, which equals approximately 580 indicated horsepower (ihp). Unless specifically noted, the "horsepower" below refers to nominal power. 
that was built in modern China (Figure 4). It can be inferred that the design of Wannian Qing might have drawn on that of the French gunboats of the La Motte-Picquet class but in a larger version (Chen 2011, 19-20). The fourth warship, Fubo (Fu-po 伏波), made some adjustments on the basis of Wannian Qing, and its design became the standard for subsequent 150-horsepower warships built by the Foochow Navy Yard.

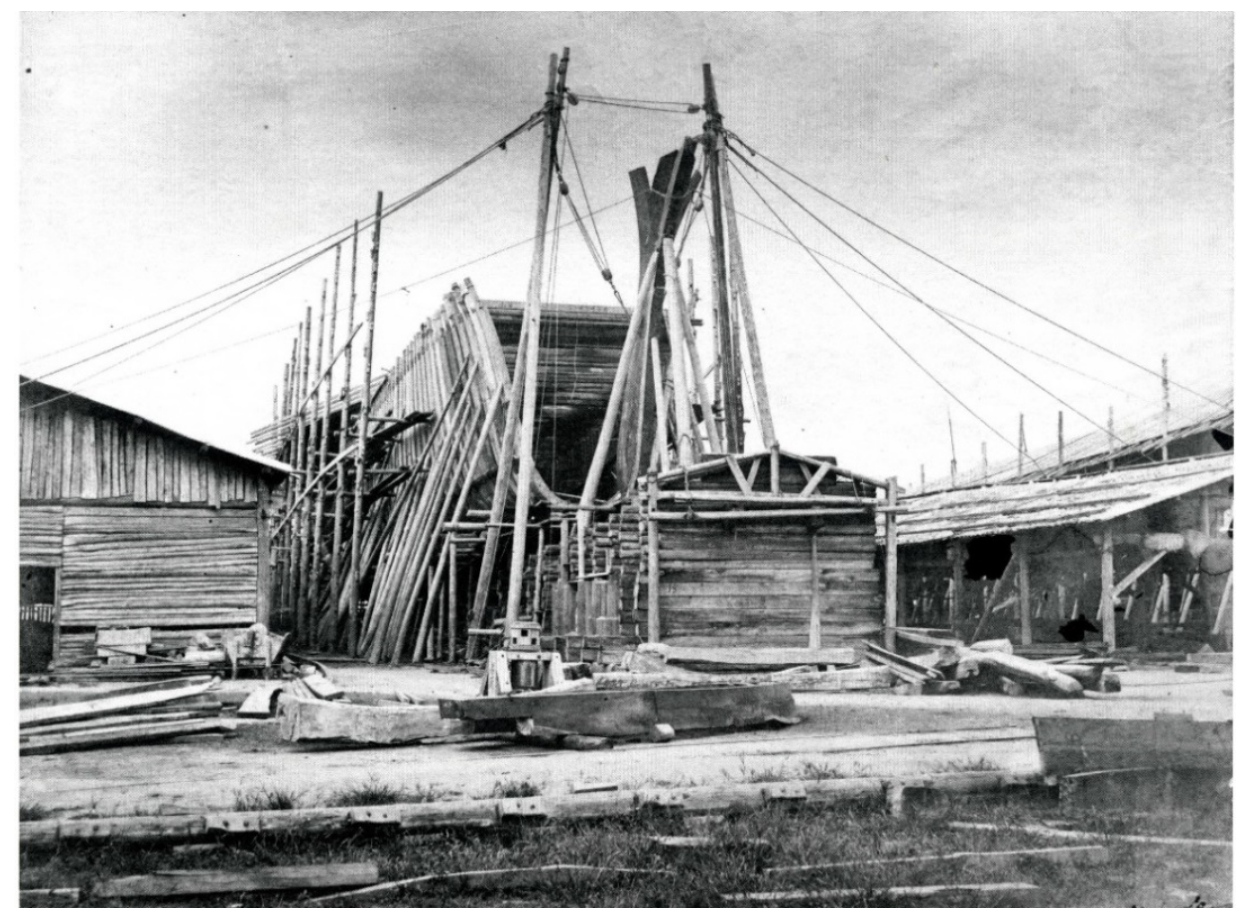

Figure 3: A ship under construction. ${ }^{19}$ Photo provided by the China Chuanzheng Culture Museum.

In shipbuilding, the work that is technically the most difficult is producing steam engines and matching boilers. While Wannian Qing and Fubo directly adopted Frenchmade $^{20}$ steam engines and matching boilers, all the 150-horsepower steam engines equipped on the subsequent seven Foochow-built vessels were built by the navy yard through imitation, with all the materials purchased from France. The imitation of steam engines and matching boilers started in August 1870 and finished in June 1871, involving the School and Office of Drawing of the navy yard and workshops on models, foundry, forging, metal-working, final assembly, boilers, and so on. After the employees of the Foochow Navy Yard dismantled the steam engine and drew a drawing, they separately produced different parts according to the drawing. Then the

19 This ship is probably Wannian Qing.

$20 \mathrm{Mr}$. Chen Yue infers that the engine was most likely built in Britain, probably in Glasgow. See Chen $(2017,158)$. More materials would be needed to verify the place of production. 
whole engine was assembled, and the boilers were imitated in the end (Feimo [1871] 2006b, 60). By way of imitating, Chinese apprentices and workmen basically mastered the design and manufacturing technique of the 150-horsepower steam engine and boilers. Of course, these products would not have counted as "advanced" in Europe, yet this imitation marked the first step for the Foochow Navy Yard to produce engines of its own and to nurture machine manufacturing talent in actual production.

While the general director of the Foochow Navy Yard Shen Baozhen was mourning his father's death at home, following Confucian protocol, his substitute, Xia Xianlun 夏 獻綸 (Hsia Hsien-lun), found the warships that had been built by the navy yard too small in size and the power of their artillery too limited. Taking the advice of Giquel, he decided to build a 250-horsepower warship. That became the gunboat Yangwu (Yang$\mathrm{wu}$ 揚武), equal to a small-sized corvette, which was launched on April 23, 1872. Yangwu adopted the double-cylinder horizontal compound steam engine produced in Glasgow, Great Britain. Since the adoption of surface condensation became general in the 1860s, compound engines were fitted to nearly all warships after 1870 (Sennett and Oram 1899, 10). The engines were arranged horizontally below the waterline in order to

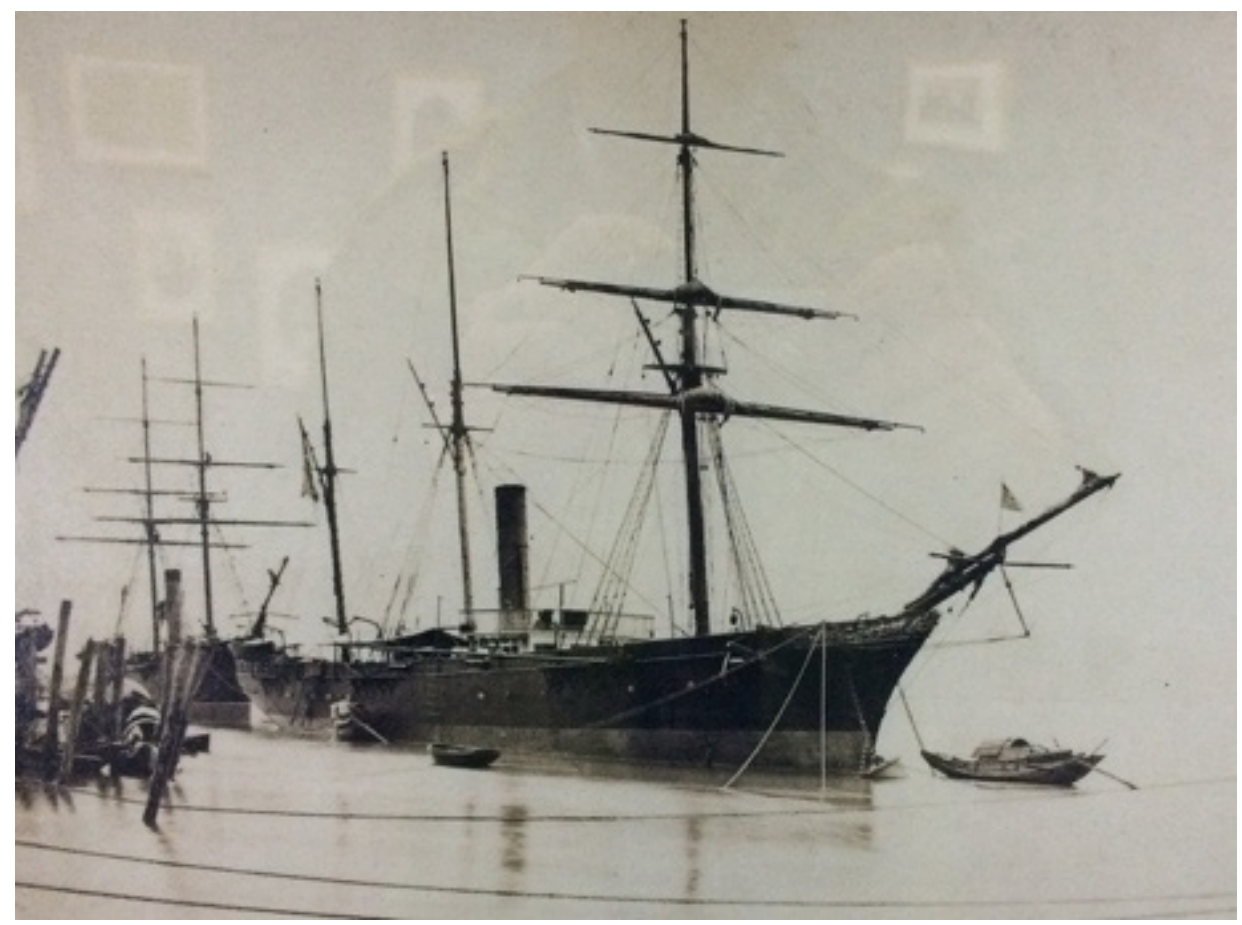

Figure 4: The gunboat Wannian Qing, equipped with a wooden frame and a wooden hull. The original photo is kept by René Viénet and was on display in the exhibition "The China Dream of a Frenchman" at the China Chuanzheng Culture Museum in December 2016. 


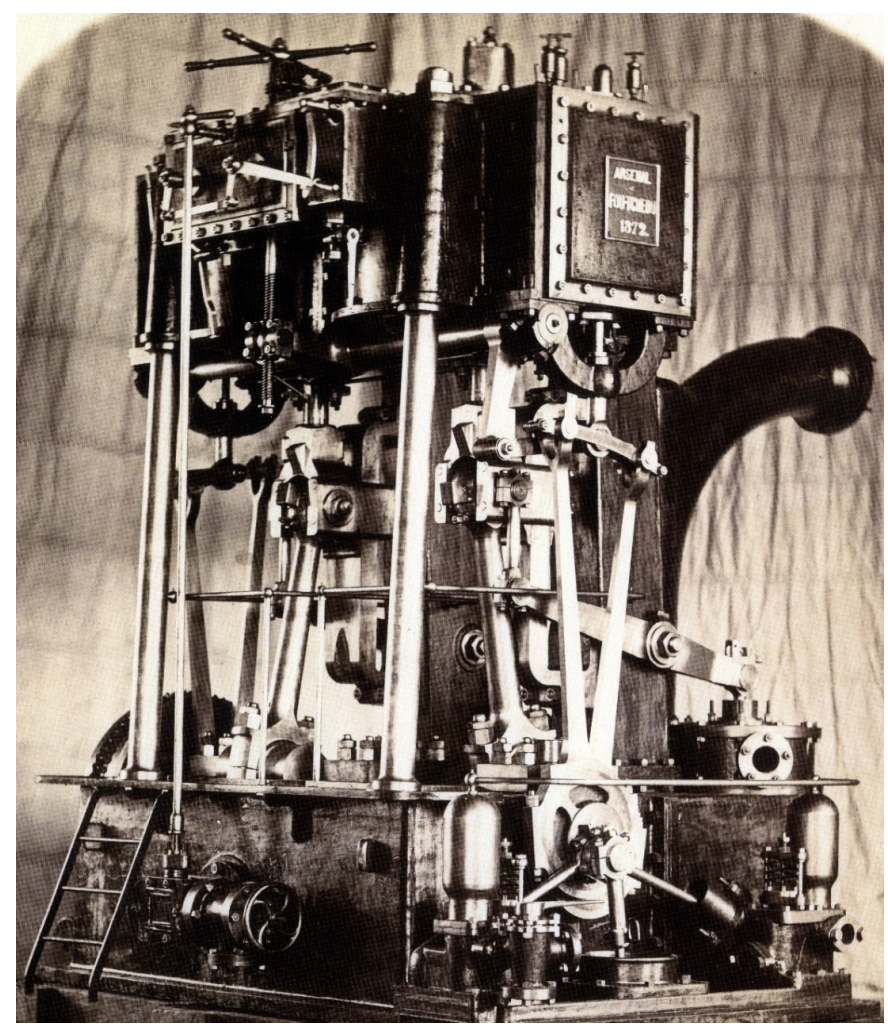

Figure 5: A steam engine manufactured by Foochow Navy Yard. ${ }^{21}$ Photo provided by the China Chuanzheng Culture Museum.

shelter them from gunfire (Feimo [1871] 2006a, 62). Yangwu was equipped with thirteen Whitworth muzzleloaders, which made the vessel the most powerful in combat among all those built during the five-year program period-it was in fact the only vessel designed purely for this purpose. ${ }^{22}$ Till the beginning of 1874, with the guidance and assistance of foreigners, the Foochow Navy Yard built fifteen warships altogether ${ }^{23}$ and

21 According to its appearance and the nameplate "ARSENAL de FOU-TCHEOU 1872," we can infer that the engine on this picture is probably a 150-horsepower double-cylinder vertical engine. 22 It is speculated that Yangwu perhaps imitated the cruiser Résolue in the French Navy (see Chen 2011, 103). The cruiser was launched in 1863 in Cherbourg and was equipped with thirteen guns, whose calibers were 6.4 inches or 5.5 inches. Originally designed as a sailing frigate, the Résolue had its keels laid as early as 1846, but it was then converted to be an unprotected cruiser driven by a steam propeller. As a product of the 1858 transformation of the French Navy, the Résolue witnessed the transition of the shipbuilding industry (see Gardiner 1979, 314-315).

23 The contract actually stipulated that sixteen warships should be built, including eleven 150horsepower warships and five 80-horsepower ones. The fifteen warships that were finally built included nine 150-horsepower warships, five 80-horsepower warships, and a 250-horsepower one. As the money and labor required to build a 250-horsepower warship surpassed that of a 150-horsepower one, the Qing government decided that the one 250-horsepower warship was equal to two 150-horsepower warships. 
trained a group of engineers and technical workers who were qualified to preside over shipbuilding. The promise was kept: Foreign employees and craftsmen including Giquel received bonuses totaling 150 thousand taels (Shen [1874] 2006, 79). In addition, some foreign employees who had made great contributions were rewarded the Imperial Order of the Double Dragon by the court of Qing, while others were rewarded commemorative plaques on which was written "Success was achieved at the Foochow Navy Yard" (船政成功), representing the Qing court's approval of the outcomes achieved in the five-year program.

At the end of the five-year program, however, the Foochow Navy Yard was still lagging far behind contemporary European shipyards. Firstly, there was a technological gap between the Foochow Navy Yard and European shipyards. In terms of material, vessels built at Foochow were all wooden warships, while shipyards in Britain and France had begun to build warships with iron hulls or even ironclads. In terms of displacement, the Foochow Navy Yard merely produced small-sized gunboats, transport ships, and commercial vessels. The only exception was Yangwu, which had a displacement of 1560 tons and barely counted as a combat ship; it could not be put in the same category as the many warships that reached a displacement of 6000 or 7000 tons. In terms of engines, the 150-horsepower steam engines that the Foochow Navy Yard imitated were far from the most advanced: The British HMS Warrior, built in 1859, had reached 5270 horsepower (indicated horsepower), which was almost ten times that of the Foochow's 150-horsepower engine. The boilers, according to Shen Baozhen's descriptions (Shen [1869] 2006a, 50), were probably low-pressure boilers with a rectangular shell, which was the most general type of marine boiler for steam pressures not exceeding 30 to $40 \mathrm{lbs}$. per square inch (Sennett and Oram 1899, 60). Such rectangular boilers had been used for a long time in the French Navy, but they were soon replaced by cylindrical boilers when higher pressures were adopted (Bertin 1896, 30-31). Secondly, as the Chinese were at that time almost completely ignorant of shipbuilding technologies in Europe, they were actually unable to make their own decisions regarding the choice of technology. In the early years of the Foochow Navy Yard, having noticed that the expenditure for the warship building program might run short, Zuo Zongtang developed the idea of building vessels that could be used for both military operations and cargo transportation. Accordingly, a cargo hold would be added to warships so that they could be employed as merchant vessels in peacetime; the revenue thus generated would be used to pay for maintenance costs (Zuo [1866] 1986, 2848). This idea of Zuo's went against common sense in shipbuilding, but was realized in the design of both Wannian Qing and subsequent vessels of the same type. The vertical engines they adopted were mostly used for merchant vessels in Europe before the 1870s, as these engines could not be kept entirely below the waterline, which made them unprotected and vulnerable in warfare (Bertin 1896, 47-48). 
Meanwhile, the vertical arrangement saved space on board and reduced the weight, which made it possible for all of the nine 150-horsepower warships to have a cargo hold, large or small - around 260 tons on Wannian Qing, and enlarged to 560 tons on Fubo. There were four others that were even transformed into transport ships. This technological and conceptual backwardness was an important impetus for the Foochow Navy Yard to upgrade its technology and dispatch students to foreign countries for further study.

\section{Building iron-ribbed warships}

At the beginning of 1875, the Foochow Navy Yard decided to shift to iron frames, and set up a workshop to process them. To get prepared for the change, Giquel went to France, where he ordered a set of iron ship frames built by Forges et chantiers de la Méditerranée and horizontal compound engines and boilers made in Britain. He also hired a group of French workmen who were familiar with the iron frames. In May 1877, the Foochow Navy Yard completed its first 150-horsepower iron-ribbed wooden-hull gunboat and named it Weiyuan (Wei-yüan 威遠). At the same time that the ship was being built under the guidance of the French, the Chinese employees of the navy yard surveyed the compound steam engine, the boiler, and the iron frame, drew the drawing, made patterns, and started to imitate. The actual production started in 1879. Weiyuan was 69.47 meters long and 9.95 meters wide, and the depth of its hold was 5.69 meters. It had a displacement of 1268 tons and a design speed of 12 knots. Weiyuan was equipped with a $170 \mathrm{~mm}$ main gun and six $120 \mathrm{~mm}$ secondary guns. The ship that Weiyuan copied was a French gunboat of the Parseval class, which was launched in 1879 (Chen 2017,376). Weiyuan, together with subsequent gunboats Chaowu (Chao-wu 超武) and Chengqing (Cheng-ch'ing 澄慶), marked the Foochow Navy Yard's shift towards iron-ribbed vessels.

In the early 1880s, the Foochow Navy Yard started to build iron-ribbed iron-hull cruisers with imported technology. Following the suggestion of the Peiyang Minister Li Hongzhang, Wu Zancheng 吳贊誠, administrator in charge of the navy yard, decided to build the new-style “fast ship that cruises" (巡遊快船) - that is, the cruiser-and bought a complete set of design drawings of the 2400-horsepower warship from Forges et chantiers de la Méditerranée. ${ }^{24}$ In 1880, Wu Zancheng ordered the students who were studying in France to copy and translate the drawings that he had bought, handed them out to the navy yard workshops, and meanwhile sent a foreign merchant to Siam to purchase timber. Around 60 to 70 percent of the iron components needed for shipbuilding were imported from abroad, while the remaining 30 to 40 percent would

24 Here the data stands for the indicated horsepower. 
be built by the navy yard itself ( $\operatorname{Li}[1881] 2006,191)$. Some of the iron parts of the steam engines and boilers, for example, were produced by foundry and iron-rolling workshops of the Foochow Navy Yard. This iron-ribbed iron-hulled cruiser was successfully completed, launched on January 11, 1883, and named Kaiji (K'ai-chi 開濟, Figure 6). With a displacement of 2200 tons, the warship's keels, ribs, and hull were all made of iron, and the hull below the waterline was covered by a copper sheet to prevent corrosion. With the help of lessons learned from copying French warships and building Kaiji, the Foochow Navy Yard went on to build another two warships of the same type, respectively called Jingqing (Ching-ch'ing 鏡清) and Huantai (Huan-t'ai 睘 泰), on which they made some improvements. To take a few examples, a bilge keel was added to each side of the bottom of the ship; the full rig was removed; machine guns were installed onto the foremast and the mizzenmast; and two blowers were added to the engine room (Pei [1886] 2006).

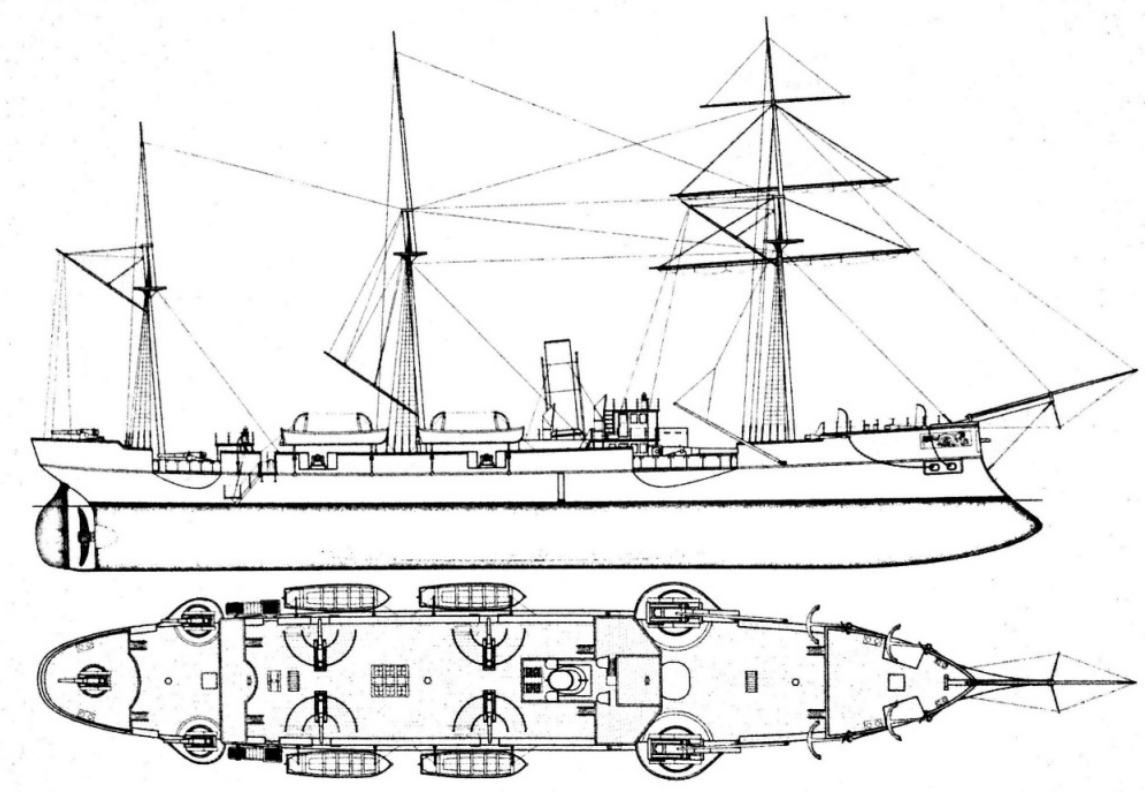

Figure 6: A diagram depicting the iron-ribbed iron-hulled cruiser Kaiji (Chen 2017, 723; the diagram was drawn by Gu Weixin 顾伟欣).

The warship Kaiji probably imitated Duguay-Trouin of the French Navy, which was launched in 1877 (Chen 2011, 182). The technological characteristics of the two warships are summarized in Table 1 . The cruiser Duguay-Trouin was a product of the French Navy's 1872 Programme. At that time, French warships were famous for an unclear, or even peculiar idea in their design. For instance, the French designers were obsessed with the tactic of ramming as well as with the deployment of large-caliber guns, in the 
hope of destroying the enemy within one or two attacks. Serving in the French Navy's overseas fleet, this kind of ship was good at cruising and convoying in foreign seas, or attacking the enemy's merchant vessel and blocking the maritime traffic, but would be destroyed very easily in a direct confrontation (Ropp 1987, 107-109). In comparison, Kaiji made small changes on the basis of Duguay-Trouin, resulting in a smaller and faster model, yet still without protective armor. As China had no actual foreign interests to protect, a warship like this might not have satisfied the country's needs.

Table 1: A comparison between the Foochow-built Kaiji and Duguay-Trouin of the French Navy ${ }^{25}$

\begin{tabular}{|c|c|c|}
\hline & Duguay-Trouin & Kaiji \\
\hline Class & Unprotected cruiser & Unprotected cruiser \\
\hline Time of keel-laying & 1873 & 1881 \\
\hline Time of launch & 1877 & 1883 \\
\hline Place of construction & Cherbourg, France & Mawei, China \\
\hline Displacement in tons & 3479 & 2200 \\
\hline $\begin{array}{l}\text { Size (length* width* displacement, } \\
\text { in meters) }\end{array}$ & $89.76^{*} 13.18^{*} 6.25$ & $83^{*} 11.5^{*} 5.44$ \\
\hline Power & $\begin{array}{l}\text { 4800-horsepower horizontal compound } \\
\text { engine and eight oval boilers }\end{array}$ & $\begin{array}{l}\text { 2400-horsepower horizontal three- } \\
\text { cylinder compound engine and eight } \\
\text { oval boilers }\end{array}$ \\
\hline Speed & 15.5 knots & 15.5 knots \\
\hline Armament & $\begin{array}{l}\text { Five } 7.6 \text {-inch M1870, five } 5.5 \text {-inch M1870, } \\
\text { ten one-pounders, and two } 14 \text {-inch } \\
\text { torpedo tubes }\end{array}$ & $\begin{array}{l}\text { Two 8.2-inch Krupp guns (main guns), } \\
\text { eight 4.7-inch Krupp guns (secondary } \\
\text { guns), and "copper blades for } \\
\text { ramming" (pengchuan tongdao 碰船铜 } \\
\text { 刀) were installed onto the prow. }\end{array}$ \\
\hline
\end{tabular}

Between 1875 and 1885, based on the technology that they had already mastered through imitation before 1875, the Foochow Navy Yard successfully upgraded its products from wood-ribbed wooden-hull warships to iron-ribbed wooden-hull warships and further to iron-ribbed iron-hull warships, becoming a shipyard capable of assembling vessels. However, there was no essential change to the navy yard's technological route in comparison to that of its early stage: the navy yard still relied on the import of designs, component parts, and materials to imitate new warships along with their matching apparatuses, such as boilers, and was still unable to design warships on its own. Nevertheless, changes occurred when the first group of students that were sent by the Foochow Navy Yard to study in France returned. Among them were Wei Han 魏瀚, Zheng Qinglian 鄭清廉, Wu Dezhang 吳德章, Li Shoutian 李壽田, Yang Lianchen 楊廉 臣, and others, who turned out to be key participants in supervising the shipbuilding.

25 Sources: Data from Gardiner (1979, 317); Li ([1883] 2006, 200-202); Chen (2017, 374-378). 
They were able to make local adjustments according to actual needs.

\section{Building ironclads}

Shen Baozhen realized the significance of ironclads as early as Japan's invasion of Taiwan in 1874. After the “Discussion concerning coastal defense" (海防議), purchasing and building ironclads became the focus of officials in charge of coastal defense (Ren 2013, 34). In 1881, the court of Qing ordered ironclads Dingyuan (Ting-yüan 定遠) and Zhenyuan (Chen-yüan 鎮遠) from Stettiner Maschinenbau AG Vulcan of Germany; the two warships, however, failed to arrive in time for the Majiang Naval Battle between China and France. In 1885, Pei Yinsen 裴蔭森, who was then the acting minister of the navy yard, submitted a memorial to the throne, pleading for appropriation to build ironclads. He held that the loss in the Majiang Naval Battle indicated that ironclads were crucial: "Building ironclads is a must if we want to reorganize and strengthen our navy" (Pei [1885] 2006a, 271-273). ${ }^{26}$ After investigation, Wei Han, Chen Zhaoao 陳兆朝, Zheng Qinglian, and some others suggested building small ironclads modeled on the French Navy's warships of the Achéron class. After Empress Dowager Cixi 慈禧 approved the plan of building ironclad vessels in 1886, Wei Han immediately went to France and Germany to purchase the steel, guns, and ammunition that were needed for shipbuilding. The construction started in December 1886 and cost 520 thousand taels. The ship, called Longwei (Lung-wei 龍威), was launched in January 1888.27 Equipped with two 2400-horsepower triple-expansion engines designed and made by the navy yard, this was the first warship built by the Foochow Navy Yard to have protective armor. Like warships of the Achéron class, Longwei also belonged to the coastal defense ironclads, and was similar to the former in many technological characteristics (Table 2). For example, both of them were covered by armor with a thickness of $203 \mathrm{~mm}$. In 1890, Longwei was commissioned into the Peiyang Squadron and renamed Pingyuan (Pingyüan 平遠, Figure 7).

Coastal defense vessels were quite popular among many maritime countries in the late nineteenth century. During the Crimean War (1853-1856), three floating batteries of the Dévastation class, designed by Pierre Armand Guieysse (1810-1891), took part in the bombardment of the Russian fortress at Kinburn. In 1859 and 1864, Stanislas-CharlesHenri-Laurent Dupuy de Lôme (1816-1885) designed two types of armored floating battery. From that point on, building small armored gunboats suitable for the defense

26 “整頓海軍必須造辦鐵甲。”

27 The ship was equipped with a $260 \mathrm{~mm}$ Krupp gun as its main gun. This was the largest main gun installed on any warship built by the Foochow Navy Yard, surpassed only by the $305 \mathrm{~mm}$ main guns on Dingyuan and Zhenyuan of the Peiyang Squadron. 
Table 2: A comparison between the Foochow-built Longwei and Pingyuan and the French Navy's warships of the Achéron class 28

\begin{tabular}{|c|c|c|}
\hline & Achéron & Longwei/Pingyuan \\
\hline Class & Armored gunboat & Ironclad \\
\hline Time of keel-laying & November 1883 & December 1886 \\
\hline Time of launch & April 1885 & January 1888 \\
\hline Place of construction & Cherbourg, France & Mawei, China \\
\hline Displacement in tons & 1690 & 2100 \\
\hline $\begin{array}{l}\text { Size (length*width* displacement, in } \\
\text { meters) }\end{array}$ & $55.2 * 12.32 * 3.56$ & $60.04 * 12.19 * 4$ \\
\hline Power & $\begin{array}{l}\text { Two horizontal compound engines } \\
\text { with a total power of } 1600 \text { horsepower } \\
\text { (indicated horsepower) and four } \\
\text { boilers }\end{array}$ & $\begin{array}{l}\text { Two three-cylinder compound } \\
\text { engines with a total power of } 2400 \\
\text { horsepower (indicated horsepower) }\end{array}$ \\
\hline Speed & $11.6-13$ knots & 12.5 knots \\
\hline Armament & $\begin{array}{l}\text { One 10.8-inch M1881, two or three 3.9- } \\
\text { inch guns, two three-pounders, and } \\
\text { four to seven one-pounders }\end{array}$ & One 260 mm Krupp gun \\
\hline Armor & $\begin{array}{l}\text { 8-inch-thick compound armor was laid } \\
\text { on the belt and the turret. }\end{array}$ & $\begin{array}{l}\text { The armor on the belt was } 203 \mathrm{~mm} \\
\text { thick. The armor that covered the } \\
\text { main battery was } 127 \mathrm{~mm} \text { thick. The } \\
\text { armor on the gun's cover and the deck } \\
\text { was } 50 \mathrm{~mm} \text { thick. }\end{array}$ \\
\hline Crew & 110 & \\
\hline
\end{tabular}

of coasts and rivers received much attention. Between 1876 and 1880, eleven armored gunboats of the Wespe class were built in AG Weser, Bremen, Germany. With a displacement of 1100 tons, they were armed with one 12-inch 35-ton gun and protected by 8-inch armor (Brassey 1888, 113). The Wespe class could be regarded as an enlarged version of the Royal Navy's Ant class and Gadfly class gunboats, ${ }^{29}$ which were also built in the 1870s for the purpose of coastal defense. Probably prompted by the German Navy, the Achéron class and the Fusée class were designed by French naval engineers Jules Victor Charles Chaudoye (1840-?) and Jean Rosier Albaret (1840-1918) in the 1880s. The two types of armored gunboats both carried heavy artillery in a turret placed in the front, sailed at a fairly considerable speed, and were equipped with a belt and an armored bridge (Hauser 1886, 527, 558-559).

28 Sources: Data from Hauser (1886, 559); Gardiner (1979, 300); Pei ([1888] 2006, 364-365); Chen (2017, 475-480).

29 They were known as flat-iron gunboats or Rendel gunboats, which were called "mosquito gunboats" (蚊子船) by the Chinese in the late Qing period. Xu Jingcheng 许景澄 (1845-1890), ambassador of the Qing government to Germany in the 1880s, claimed that the Wespe class "followed and slightly enlarged the design" (因其制而稍拓之) of mosquito gunboats (see Xu $1885 \mathrm{~b}, 9)$. He also claimed that the eight gunboats of the Achéron class and the Fusée class were imitating the Wespe class (see Xu 1885a, 15). 


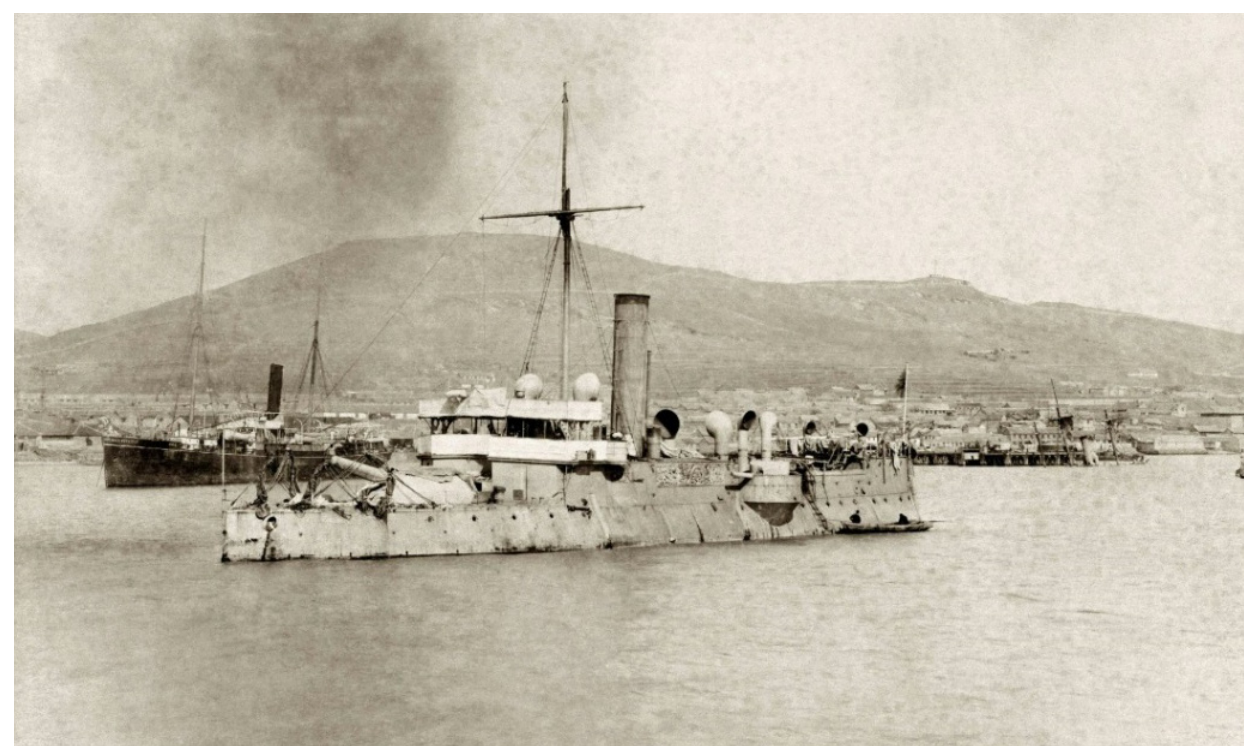

Figure 7: Pingyuan after being captured by the Japanese Navy during the First Sino-Japanese War. Photo provided by the China Chuanzheng Culture Museum.

Starting in the 1870s, important changes occurred in the development strategy of the French Navy. Having been defeated in the Franco-Prussian War, the French Navy suffered from a lack of financial support and decreasing public attention. Consequently, the arms race with the British Navy was given up. The French Navy retreated to a focus on protecting its overseas colonies and offshore defense with regard to Germany. The building of cruisers, coastal defense ships, and torpedo boats was thus emphasized (Ropp 1987, 26-35). At that time, in the French fleets that were stationed in the foreign colonies, including the fleet in the Far East that participated in the Sino-French War, a majority of the warships were without armor. Wei Han and others must have had some knowledge of the strategy of the French naval forces; further upset by the defeat that China suffered in the Majiang Naval Battle, they might have believed that coastal defense ironclads could effectively attack warships which had no armor, and was thus the right choice to defend the Chinese coastal areas and its territorial seas. Some scholars claim that choosing to imitate warships of the Achéron class exposed the professional incompetence of the Foochow Navy Yard School's graduates (Ma 2013, 127-136). The author of this paper, however, holds that Wei Han and others might have considered both technological characteristics and factors like the shipway's size and the limits on spending before they chose warships of the Acheron class. The shipway of Mawei was located inland on the Minjiang River 闽江, which set a limit on the maximum size and draft of the vessels built by the navy yard. Longwei was small in size, but its main gun had a relatively large caliber, so the ship could be regarded as a floating armored battery.

As technology developed, armored torpedo-cruisers also became the model for the 
Foochow Navy Yard. In the mid-to-late nineteenth century, cruisers had two main means of protection. One was to lay armor on the belt, which would sacrifice the ship's speed, as the armor would cover a relatively large area. The other was to add an iron deck like a turtle shell to the interior of the warship to prevent attacks from above and to prevent water leakage caused by side penetration. The Guangyi (Kuang-i 广乙), Guangbing (Kuang-ping 广丙), and Guangding (Kuang-ting 广丁), successively built by the Foochow Navy Yard, were torpedo cruisers with armored decks. The construction of Guangyi started in January 1888, and the ship was launched on August 28, 1889. The warship had a steel structure and was equipped with a $25.4 \mathrm{~mm}$ thick armored deck inside. Guangyi was 71.63 meters long and 8.23 meters wide, with a draft of 3.96 meters and a displacement of 1000 tons. The ship used the 2400-horsepower compound steam engine imported from Europe, and sailed at a speed of 15 knots. It was equipped with four 14-inch torpedo tubes and small- and medium-sized Krupp guns. Guangyi imitated torpedo cruisers of the Condor class in the French Navy. The latter's design speed was 17 to 17.5 knots, and it had a $41 \mathrm{~mm}$ thick armored deck inside.

During the decade between the Sino-French War and the First Sino-Japanese War, the shortfall in funds for the Foochow Navy Yard reached 2.5 million taels. As a consequence, the navy yard started to dismiss its officials and workmen and merged or even shut down some of its workshops. At the same time, however, in order to build the new steel-armored warships and torpedo cruisers with added armored decks, the navy yard expanded its production area, mainly with new equipment to process steel. In 1886, a new torpedo factory was set up in the shipyard. Chen Caiduan 陈才鍴, who had studied torpedo manufacturing in France, was in charge of instructing craftsmen how to assemble, maintain, and imitate torpedoes in the factory. Thus, it can be seen that despite financial difficulties, the Foochow Navy Yard continued to improve its technology and carried on with the production mode of "purchase-imitate-assemble."

\section{Nurturing naval engineers and technical workers}

Modern French technical education started early and formed its own tradition. In nineteenth-century France, science courses were very important in primary and secondary education, while mathematics accounted for a significant proportion of the curriculum in public high schools (lycée) and commercial high schools (collège communale) (Soley 1880, 115-116). Some high school graduates were either directly admitted to the École Polytechnique or admitted after a year of matriculation to receive a two-year education which primarily consisted of theoretical courses. Graduates who intended to become naval architects had to study for another two years at the École du génie maritime. Those who graduated would become assistant engineers of the third class and would be qualified to join the manufacturing engineer team of the French 
Navy (Corps du génie maritime) (Soley 1880, 94). Therefore, a high school graduate would have to finish seven or eight years of training before becoming a naval architect. Centering on the École Polytechnique, this system (système polytechnicien) connected secondary education and higher professional education and could be applied to the training of engineers specializing in shipbuilding, guns and cannons, roads and bridges, and mining (Belhoste 2003,39-40). This pattern of education gradually came into being after the French Revolution. It was already very mature by the mid-nineteenth century, and had nurtured a large number of engineers.

Attaching great importance to the role of the Foochow Navy Yard in imparting technological knowledge, the Chinese officials expected that these foreigners could help to train students to be able to supervise shipbuilding and operate a ship. Even before the construction of the shipyard commenced, the Technical Division of Qiushi Tang (Ch'iu-shih T'ang) 求是堂藝局 had been established in the Foochow Navy Yard to train the students to operate ships. After Shen Baozhen had been appointed as the general director of the shipyard, the Technical Division was expanded to contain the French Schools and the English Schools. The French Division included the School of Naval Construction (Zhizao xuetang 製造學堂), the School and Office of Drawing, and the School for Apprentices (Yipu 艺圃). ${ }^{30}$ This part of the school was closely related to the production department of the navy yard, and mainly hired French instructors. The English Division ${ }^{31}$ consisted of the Naval School (Jiashi xuetang 驾驶学堂), the School of Practical Navigation (Lianchuan xuetang 練船學堂), and the School of Engineers (Guanlun xuetang 管輪學堂). ${ }^{32}$ According to the contract that Giquel and others signed with the Chinese, within five years, the French Division was to train its students to be capable of “constructing ships independently on a given plan" (按圖自造). In a society

30 The French Division had been lecturing in French since the five-year program period. In the 1880s, as Sino-French relations worsened, Leon Médard, former French instructor of the French Division, was laid off. In May 1885, under the commission of the former acting minister of the navy yard, Zhang Peilun 張佩綸, Zeng Jize 曾紀澤 employed F. T. Richard as the first British instructor of the French Division. As students of this division had been learning French for three or four years, they were not going to shift to learn English. After Pei Yinsen 裴蔭森, who was then the acting minister of the navy yard, enrolled more than a hundred children into the school to learn English, the French Division started to instruct in English. French instruction did not resume until the French technicians led by Charles Doyère arrived in 1896. See Pei ([1885] 2006b, 278-279); Hitara ([1897] 2006a, 470-471).

31 At that time, English was almost the official language of the Chinese Customs and maritime affairs, so courses related to navigation and steam engines had to be taught in English. Moreover, the instructor of the English Division was from Britain. The English Division produced many talents for the Chinese Navy.

32 In Giquel's French report, he used the following terms to refer to different parts of the school: École de construction navale (School of Naval Construction), École et bureau de dessin (School and Office of Drawing), Écoles d'apprentis (School for Apprentices), École navale (Naval School), Navire école (School of Practical Navigation), and École des mécaniciens (School of Engineers). 
where science education in primary and secondary school was basically absent, the School of Naval Construction had to squeeze all the necessary courses and practical learning, which actually belonged to different stages of education, into five years.

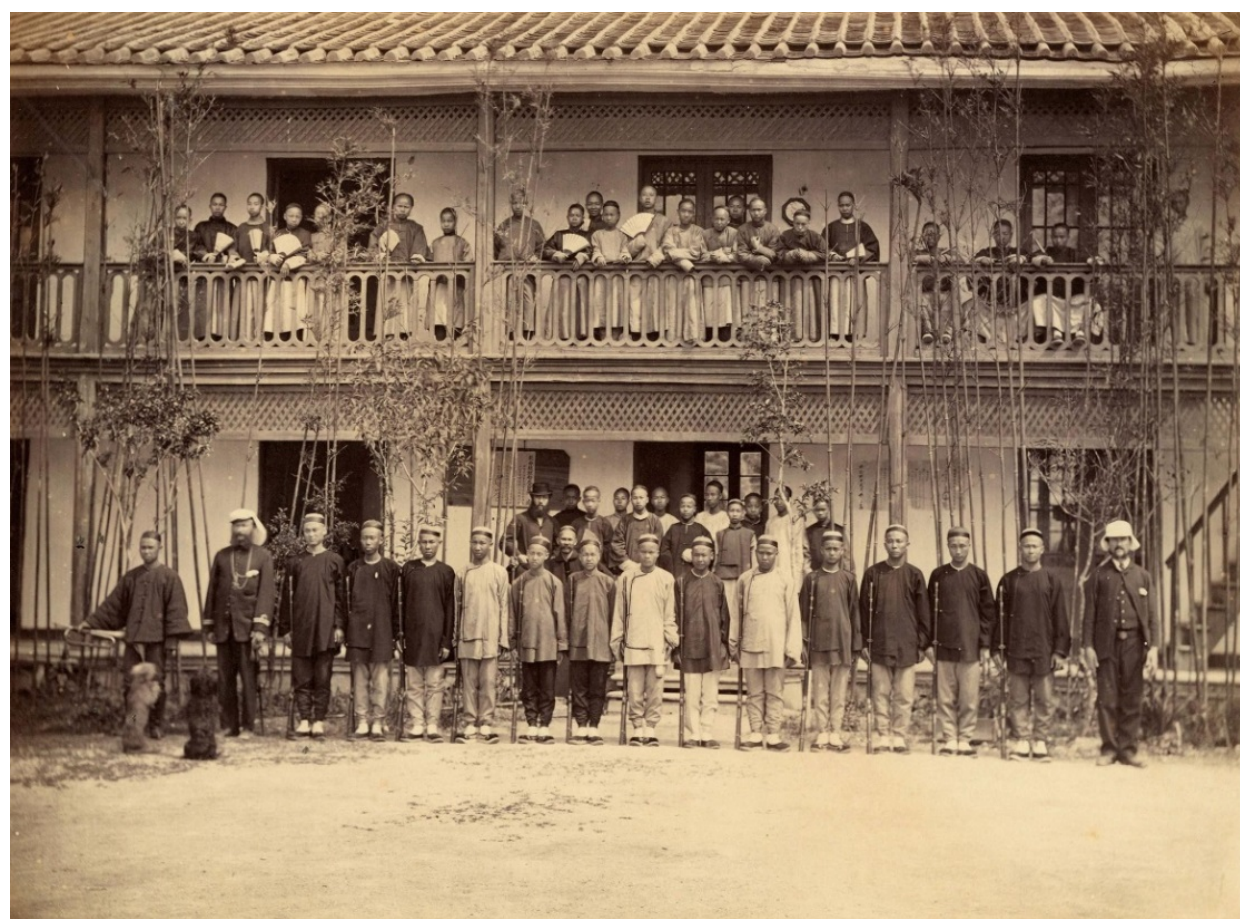

Figure 8: A group photo of the students from the Naval School. Photo provided by the China Chuanzheng Culture Museum.

Founded in February 1867, the School of Naval Construction mainly trained field engineers, aiming to prepare its students to calculate and design the hull of a wooden warship, and make them capable of designing and building machines. The training at the school lasted five years, and students were divided into four classes according to academic level. The first and second classes taught faster compared to the third and fourth classes. Drawing lessons from the education system of France, the school offered many mathematical courses, such as arithmetic, elementary algebra, elementary geometry, descriptive geometry, trigonometry, analytical geometry, and calculus. In addition, there were theoretical courses like physics and mechanics, and practical training involving subjects like the driving engines of machine-tools and the resistance of the shafts, the tooth and pinion wheels, and the pulleys. As for power, there were foreign craftsmen who taught the construction of boilers and steam engines, as well as how to calculate their power. Meanwhile, the workshop foremen were in charge of explaining and demonstrating the operation of steam engines to students who specialized in building engines (Giquel 1874, 16-18). In the later phase of the navy yard, the French engineer 
Charles Doyère ${ }^{33}$ extended the length of training at the French Division from five years to six years, and explicitly required that the students first learn elementary and intermediate mathematics in accordance with the curriculum of French elementary schools and navy schools, and then learn advanced algebra, analytic geometry, and calculus in the last two years (Hitara [1897] 2006a, 471). It can be said that the School of Naval Construction adopted a compressed version of the École Polytechnique's system, as it integrated and simplified the seven-to-eight-year curriculum and practical training of French high schools, the École Polytechnique, and naval engineering schools.

The School and Office of Drawing aimed to train draftsmen who could work together with engineers. After studying for some time, the school's students were divided into three classes. The ten students of the first class were transferred to the School of Naval Construction, while the second and the third classes had eleven students each. Courses offered in the School and Office of Drawing, which included arithmetic, geometry, descriptive geometry, and a course on analyzing the construction of the 150-horsepower steam engine employed on ships, were fewer in number and easier than those of the School of Naval Construction. Competent draftsmen were expected to be able to calculate and design different parts of an engine according to the ideas and requirements put forward by engineers. In order to achieve this level, students not only needed to master basic drawing skills and geometrical knowledge, but also needed some experience in actual production so as to thoroughly understand the construction and processing technology of the machine. In practice, however, students of the School and Office of Drawing failed to meet this requirement. On the one hand, most of these students were those who had gotten relatively low grades in mathematics in the School of Naval Construction. On the other hand, the production department of the navy yard was not able to provide enough practical experience for the students to fully understand the machinery (Giquel 1874, 24).

In need of skilled workers for its production department, the navy yard set up the School for Apprentices, transplanting the model of French night schools. This model had proven effective in nurturing the kind of technical workers that were indispensable to the development of modern industry. The navy yard recruited young men who were fifteen to eighteen years old, physically strong, and mentally acute, and trained them as apprentices. After the number of apprentices had reached a certain scale, the apprentice department was established (Shen [1868] 2006, 41). In addition to learning technologies, the apprentices learned to read plans and to calculate the volume and weight of the hull

33 Charles Doyère (1858-1929), a chief engineer of shipbuilding and the assistant director of École d'application du génie maritime, became the head of technical office of naval construction in 1896. He was hired by the Qing government in 1897 to reorganize the Foochow Navy Yard, and was dismissed in 1903 for he privately signed a shipbuilding contract with Racine Ackermann et Cie 立兴洋行. 
and the component parts of an engine. From 1868 to 1870, these apprentices were scattered in different workshops, learning French every night. In November 1870, they began to take courses including arithmetic, geometry, descriptive geometry, and algebra, as well as a thorough course on steam engines. In 1871, they were divided into four classes according to the academic progress that they had made, and from that point on were tutored by foreign craftsmen in different workshops. By the time the program was finished, apprentices of the first two classes had basically reached the expected level, with the outstanding ones qualified to hold the post of foreman. Apprentices of the third and fourth classes, on the other hand, were not that satisfactory (Giquel 1874, 24-26).

The School of Naval Construction recruited two groups of students, altogether 105, during the first five years, but only 39 remained at the beginning of $1874 .{ }^{34}$ The first and second classes finished all the theoretical courses and practical training, and fourteen students of these two classes were assigned to different workshops of the navy yard. The most outstanding students were qualified for the position of workshop director, while those who were less promising and those from the third and fourth classes could serve as their assistants (Giquel 1874, 18-22). By 1873, workshops on models, foundry, fitting, and boilers had been able to operate independently without the guidance and supervision of foreign craftsmen (Giquel 1874, 26-32). By the time the five-year program came to an end, the workshop for foundry had basically acquired the capability to independently make forge parts for the steam engine. In 1875, the Foochow Navy Yard commenced building the first warship of its own design, the 50horsepower small wooden gunboat Yixin (I-hsin 藝新), which had a displacement of 245 tons. The construction was directed by the first group of students trained by the School of Naval Construction. Among them, hull engineers Wu Dezhang, Luo Zhenlu 羅臻祿, and You Xueshi 遊學詩 drew the hull's plan, while marine engineer Wang Qiaonian 汪喬年 drew the plan for the steam engine (Ding [1876] 2006, 122-123). Thus, it can be seen that graduates of the School of Naval Construction could take charge of tasks in the production.

Nevertheless, the "crash course" method of training in the School of Naval Construction has its inherent shortcomings, and there was an obvious gap between the school and its counterparts in France. In fact, it was extremely difficult for a young Chinese man who started from the very beginning to master French, modern mathematics and physics, and technology, and thus fulfill the requirements for an assistant engineer of the third class in

34 The appraisal system of the navy yard's school was very strict so a large number of students would be weeded out. While the Qiushi Tang Technical Division was in session, there were examinations every three months. The students who ranked at the top would receive a prize of ten foreign silver dollars; those who ranked in the middle were neither rewarded nor punished; and those who ranked at the bottom were given a demerit for laziness. Two consecutive demerits led to punishment, while three led to dismissal. Those who received three prizes in a row would be rewarded with extra material for clothing. 


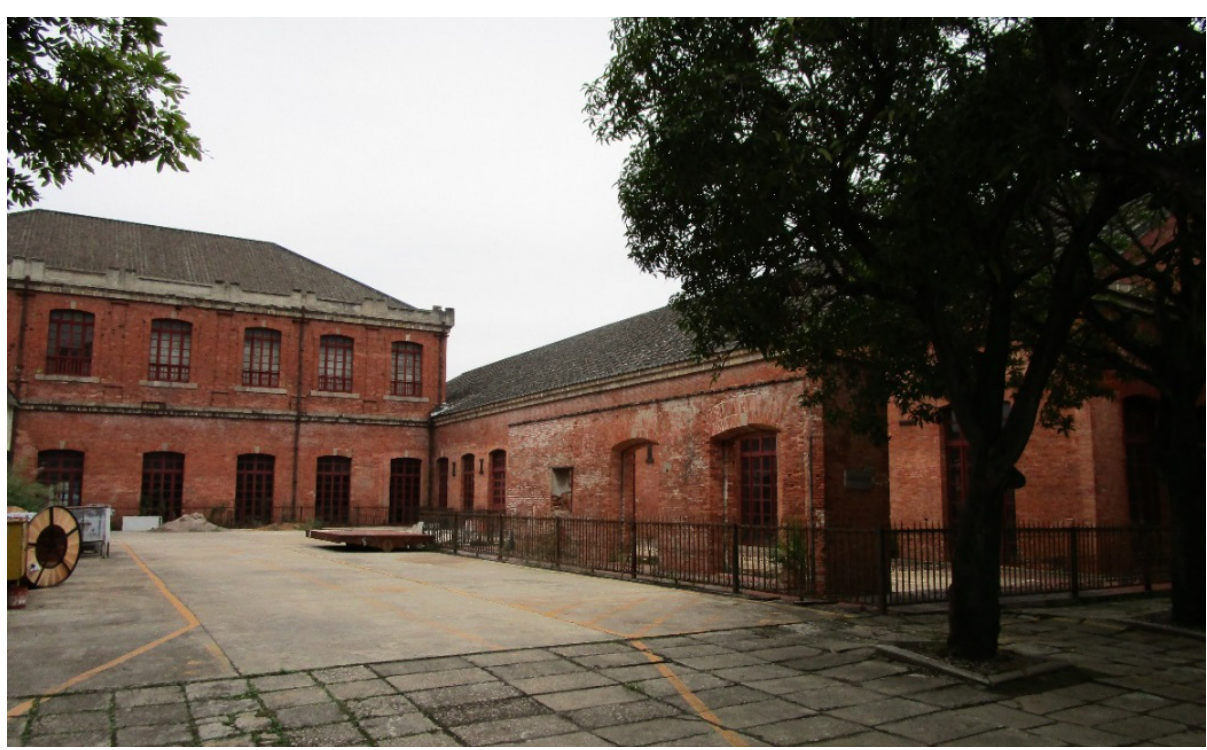

Figure 9: Industrial heritages of Foochow Navy Yard. The two-story building on the left consists of an assembly shop (first floor) and the School and Office of Drawing (second floor), and the building on the right is the engine-manufacturing shop. Photo by Li Mingyang.

the French Navy in merely five years. Giquel admitted that they had neither the time nor the means to train students to be qualified engineers capable of designing a whole machine and managing the production of a whole factory. At that time, China did not have such an industrial environment, so it was necessary for students to go to European factories to acquire more practical experience and stay for at least four years (Giquel 1874, 19). It was also necessary for students of the School and Office of Drawing, apprentices of the School for Apprentices, and students of the Naval School to go to Europe for further study or practical training (Giquel 1874, 24, 25, 41). The reasons why Giquel made great efforts to facilitate the navy yard's project of sending students to foreign countries might have included his desire to continue enjoying the high salary provided by the Qing government, and meanwhile to earn a reputation in France. ${ }^{35}$

Another fact that should not be ignored is that the navy yard school exhibited characteristics of Chinese culture. Shen Baozhen believed that "it is proper to master skills of foreign countries with a Chinese mind, while it is improper to allow foreign customs to transform the Chinese temperament." 36 Therefore he required students to

35 This was pointed out by Li Hongzhang in an 1876 letter to Wu Zancheng, who was then the administrator of the navy yard: "After the work of the navy yard had been finished and the foreigners withdrew, Giquel and assisting foreign employees stayed at the navy yard, squandering the salary for three years for nothing but sending students abroad" (日意格與幫辦洋 員, 自船工告成、撤退洋人後, 留工虛糜薪費三年於茲, 專為出洋一事). See Li ([1876] 2008, 487). 36 “以中國之心思通外國之技巧, 可也; 以外國之習氣變中國之性情, 不可也。” 
read The Sacred Edict (Shengyu guangxun 聖諭廣訓) and Classic of Filial Piety (Xiaojing 孝經) every day after class, and to practice writing Chinese essays on political issues (Shen [1867] 2006, 24). Confucian culture was also manifested in the fact that the school put a limit on "romping" (xiyou 嬉遊) and retained the "hundred days of funeral leave" (bairi sangjia 百日喪假). These practices embodied Shen Baozhen's idea of education, which was to nurture "Confucian engineers" (Pong 1994, 228-230, 234-235).

\title{
6 Studying in France
}

The French government took a welcoming attitude towards Chinese students. In 1867, the French foreign minister wrote in his letter to the French envoy to China that:

\begin{abstract}
We should encourage the Chinese Government to send as many students as possible to our country, to learn specified knowledge, and to learn our language, and directly provide information about schools, academic institutes, and industrial facilities of our country to their government. On our side, we ought to provide all the necessary conveniences to these students, so that they can quickly bring back what they have learned to their own country. (Bastid-Bruguière 1991, 192) ${ }^{37}$
\end{abstract}

When the five-year program ended at the beginning of 1874, Shen Baozhen submitted a memorial to the throne that proposed sending graduates of the navy yard school to Europe for further study. After Giquel had formulated a plan and discussed with the Ministry of Foreign Affairs in the Qing government (Zongli yamen or Tsungli yamen 總理衙門), the Foochow Navy Yard decided to dispatch some graduates of the French Division Wei Han, Chen Zhaoao, and Chen Jitong 陳季同 - and of the English Division Liu Buchan 劉步蟾 and Lin Taizeng 林泰曾 - to accompany Giquel to purchase machinery and materials in Britain and France, while making tours of investigation (Shen [1875] 2006, 103). The plan to send students abroad had not been implemented until Shen Baozhen left office and Ding Richang 丁日昌 (Ting Jih-ch'ang) succeeded as the administrator of the Foochow Navy Yard. The Japanese invasion of Taiwan in 1874 brought the issue of coastal defense to the forefront and triggered discussion throughout the Qing government. The plan proposed by Shen Baozhen and Ding Richang finally won the support of Li Hongzhang. In March 1877, the first group

37 “. . . il serait d'une bonne politique d'encourager le gouvt. Chinois à envoyer le plus souvent qu'il le pourra en France des gens chargés de le renseigner par eux mêmes sur nos écoles, nos établissements scientifiques et industriels, $d^{\prime} y$ apprendre notre langue, $d^{\prime} y$ suivre des cours et à qui nous financerions de nôtre côté toutes les facilités nécessaires pour ces études dont ils rapporteraient ensuite les fruits dans leur pays."

The original French text is not included in Bastid-Bruguière's paper. The French quotation here is cited from 동북아역사넷 (Northeast Asian History Network), http://contents.nahf.or.kr/ item/item.do?levelId=gk.d_0002_1270, accessed May 17, 2020. 
of students from the navy yard's school were sent to Europe for three years of study abroad.

From 1877 to the end of the Qing dynasty, four groups of students were sent to France $^{38}$ by the navy yard's school, totaling over fifty. Among them, the first group was the largest, consisting of twenty-five students, including the graduates of the School of Naval Construction and the School for Apprentices. As the French schools could only accommodate a certain number of visitors, only four of the students entered the École du génie maritime to learn how to build hulls and steam engines (Figure 10), while others were sent to schools including the École des mineurs de Saint-Étienne and the École des mines de Paris to learn mining (Figure 11) and casting cannons and guns. Students from the School for Apprentices were sent to schools that trained technical workers, for example, the École d'arts et métiers, Châlons-sur-Marne. In addition to learning at school, a majority of the students also had the chance to practice in stateowned arsenals or to inspect these factories. The first group of students that were sent to foreign countries were directly admitted into specialized large schools rather than entering the École Polytechnique first, indicating that by the time they went abroad, they had already reached at least the level of École Polytechnique graduates. Of course, those who were dispatched to study overseas were the most outstanding among all the graduates of the navy yard's school; most of them had been praised by Giquel in his report, and had a few years of practical experience after graduation. When they were in France, these students received “the most careful guidance" (盡心指授) from French instructors and engineers ( $\mathrm{Li}$ [1880] 1961, 239-241).

The doors of French schools were open to the rest of the world, but there were limits to this opening. According to the regulations, foreign students who had gotten the French government's permission and passed the entrance examination could attend classes as auditors and could also obtain corresponding diplomas after graduation. However, unlike domestic students, the international students were not allowed to live on campus (Hazen 1872, 269), which increased the cost of studying abroad. ${ }^{39}$ Besides, only under special authorization could the international students access the drawings and documents in the school's archives; it was thus very difficult for them to reach the technical literature that was the most important and up-to-date (Soley 1880, 143-144). It was actually reasonable for technical schools to keep confidential information from international students. The Sino-French War broke out when the second group of students from the navy yard was studying in France. As a consequence, these students

38 Several of these students were sent to Germany halfway through.

39 Take the expenses of the fourth group of students as an example. When Yulu 裕祿 made a budget for them according to the expenses of the third group, the estimated total cost of six years amounted to more than 107,000 taels, of which the rent and housing renovation alone would cost more than 22,000 taels. See Hitara ([1897] 2006b, 473-478). 


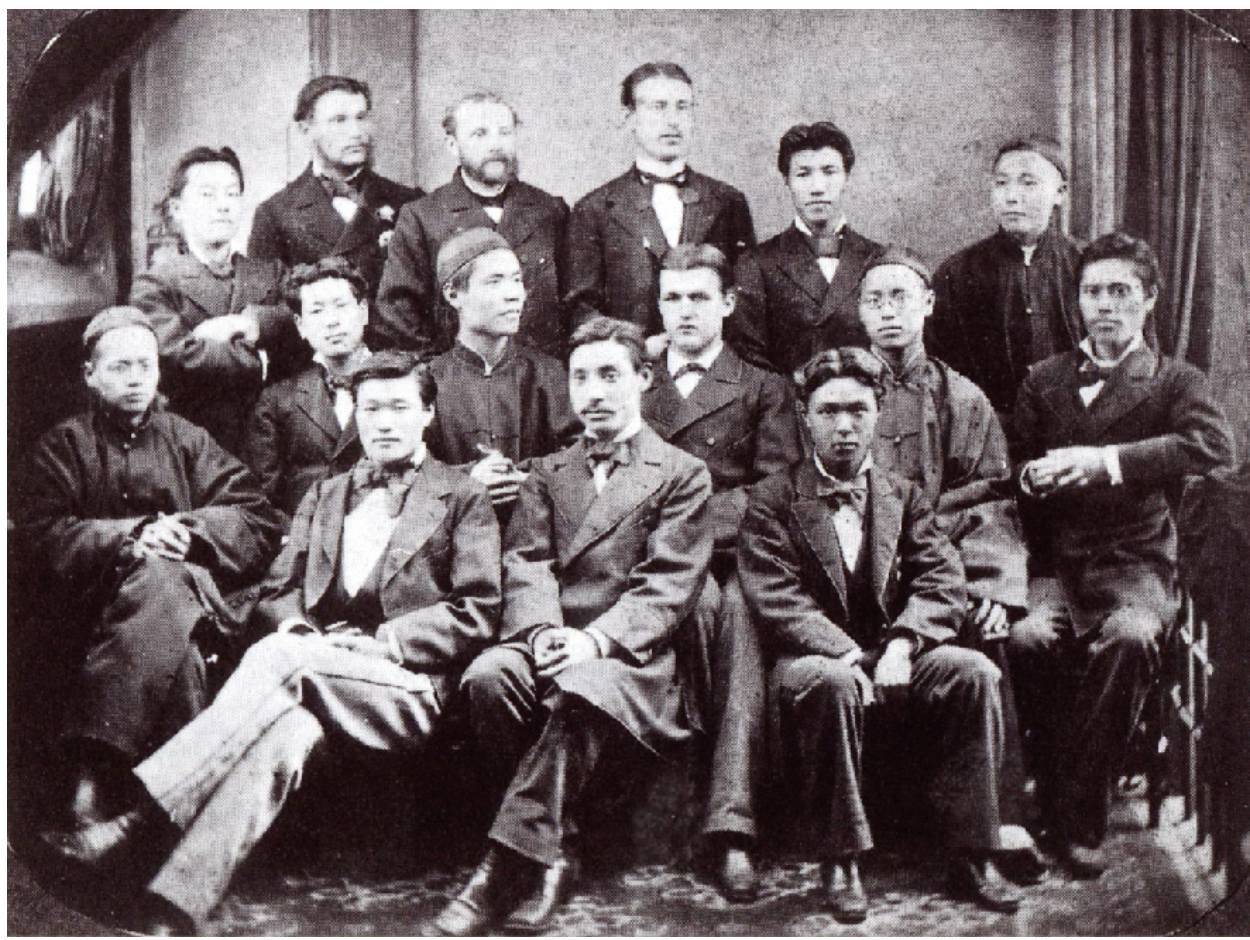

Figure 10: A group photo of foreign students who were studying at the École d'application du génie maritime. Among them were four Chinese students, Chen Linzhang 陳林璋, Wei Han, Zheng Qinglian, and Chen Zhaoao. Photo provided by the China Chuanzheng Culture Museum.

were strictly forbidden to access any information except course materials (BastidBruguière 1991, 196). To some extent, the various restrictions had a negative effect on the Chinese students' learning.

The Chinese students cherished the opportunity to study abroad and made great efforts to learn new knowledge and new technology. When the first group of students was in France, Guo Songtao 郭嵩壽, who was serving as the envoy to Britain and France, paid close attention to these students' performance at school; he even read the Chinese students' diaries. According to Guo Songtao's diary, in addition to studying at the École des mineurs de Saint-Étienne and the École des mines de Paris, Luo Zhenlu had also visited Belgium to inspect the mining industry there (Guo [1878] 1984a, 696). In his diary, Luo recorded the principle and procedure of the Bessemer process and the Martin process, the process of making refractory bricks for blast furnaces, the technique adopted by Chantiers de La Seyne that used a hot pressing method to rapidly manufacture bot heads for ships, and so on (Guo [1878] 1984c, 612-614). Another Chinese student, Wu Dezhang, majored in manufacturing and was praised by Guo as “especially dedicated to learning” (向學為篤) (Guo [1878] 1984b, 607). Wu wrote an 


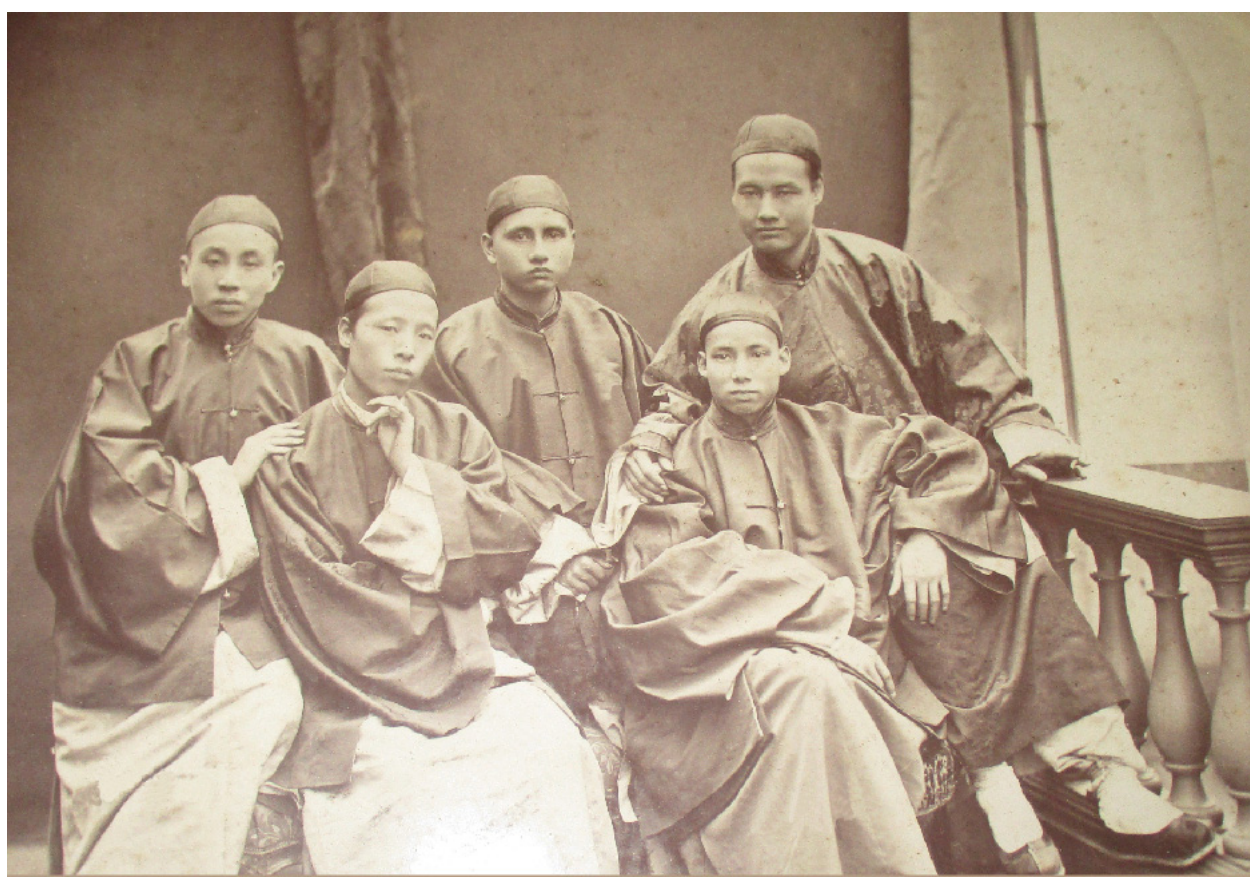

Figure 11: A group photo of the five students (Zhang Jinsheng 張金生, Lin Qingsheng 林慶升, Lin Rizhang 林日章, Chi Zhenquan 池貞銓, and Luo Zhenlu) that were studying mining in France. Photo provided by the China Chuanzheng Culture Museum.

article entitled "A Brief Introduction to the Geometrical Knowledge Related to Ships' Design" (Chuanshen yu jihe shuolüe 船身御幾何說略), introducing knowledge such as the floatability of vessels, the three-view drawing of hulls, and the design of hulls' structure, and emphasizing the important role that the mechanics of materials played in building iron vessels and machinery (Guo [1878] 1984b, 600-605). Luo claimed that at the Foochow Navy Yard's school, he had only "a brief knowledge of science and mathematics" (粗明格致算法). “Calculus, mechanics of materials, mechanics, and kinematics” (微積編、釿學、重學、運動諸法) that he learned in France “were something that I had never read about. I have gotten the chance to investigate these subjects one by one, to make clear their principles, and to learn about their origins" (皆 素所未讀, 並得逐一推考, 澈委知源) (Guo [1878] 1984b, 607). From Wu's experience, we can see that the training at the navy yard's school emphasized practice, while the students' learning in France supplemented this with theoretical knowledge.

Starting with the second group, the students that were sent by the navy yard to study in France decreased both in number and in quality. On the one hand, as some of the students had been transferred to the Peiyang and Nanyang Squadrons, while some other graduates had been retained by the navy yard to work there, there were barely 
enough students to be chosen from (Chen 2017, 412). On the other hand, after Shen Baozhen passed away, the project of dispatching students to France for further study was getting less and less attention. The second, third, and fourth groups that were sent to France, Britain, and Germany added up to twenty-eight students in total. Rather than majoring in manufacturing and mining, they gradually shifted to weapons, civil engineering, and law. For instance, the third group, consisting of fourteen members, left for France in 1886. Two of them entered the École du génie maritime to learn shipbuilding, while others were enrolled at the École des ponts et chaussées, École normale supérieure, or Faculté de droit de Paris to major in civil engineering, mathematical physics, or law. The time that they stayed abroad to study was extended to six years (Pei [1890] 2006, 402-403). If we look at their performance while learning abroad and subsequent career development, the first group of students was not only the largest in number but also achieved the most. After returning to China, most of them became key members in shipbuilding and teaching at the Foochow Navy Yard, either serving as heads of the production department or as instructors of the school.

\section{Conclusion}

With the help of Prosper Giquel and some others, the self-strengtheners among Qing officials imported French technology and machinery to set up the Foochow Navy Yard, which could both build ships and provide technological education. During the fiveyear period stipulated by the contract, and making use of the drawings, machinery, and materials from France, the navy yard built small-sized wooden warships or warships that could also transfer cargo, and imitated French steam engines. At the same time, Chinese engineers and technical workers started to take over the navy yard's production, succeeding in designing and constructing a small gunboat in 1875. It was at this time that the European shipbuilding industry underwent an upgrade in technology and a transformation of production: iron-framed, iron-hull warships or even ironclad ones started to be built and wooden warships began to withdraw from the stage of history. As a matter of fact, the Foochow Navy Yard failed to achieve a high level of technological independence. There was always a large gap between it and the advanced shipyards in Europe and the United States; it produced low-level warships at a high cost. Shen Baozhen realized this as early as his time as Nanyang minister (18751879), so he reached a tacit understanding with Li Hongzhang to favor the Peiyang Squadron in arranging the navy's expenditure and talents. More advanced warships were imported for the Peiyang Squadron, and outstanding graduates of the navy yard's school were sent there as well. This shows that at that time, the shipbuilding was to some extent out of line with the development of the navy.

The Foochow Navy Yard condensed French secondary education, higher education, 
and professional higher education into the training at the School of Naval Construction, and complemented this school with the School and Office of Drawing, the School for Apprentices, and various workshops, formulating a talent-nurturing system which combined schools and factories. Engineers trained by the School of Naval Construction, including those few who had been to France for further education, were able to imitate foreign products and make local revisions. Nevertheless, they could hardly design and develop any new advanced warships, so the Foochow Navy Yard had to continue importing technology after 1874 to upgrade its products, meanwhile imitating ironframed wooden-hull warships, iron-framed iron-hull cruisers, ironclads, and matching equipment including compound steam engines. The construction of new warships still required the assistance of French engineers or craftsmen. Moreover, in fields other than shipbuilding, the technological talents that the navy yard's school nurtured at a high cost were almost of no avail. On the one hand, Chinese industrial enterprises were few in number and small in size, providing very limited space for the career development of technical personnel. On the other hand, as these people stayed away from the imperial examination system, they were not able to access the world of bureaucracy with the technical knowledge that they had acquired.

\section{Acknowledgments}

This paper is based on part of the author's doctoral dissertation. The author would like to express his gratitude to his supervisor, Prof. Zhang Baichun 张柏春 for his guidance on this paper. The author is also indebted to Prof. Bruno Belhoste for his instruction during the initial period of this research, to Prof. Darina Martykánová for inspiring the author with her research on France-trained engineers from Spain and the Ottoman Empire in the nineteenth century, to Mr. Chen Yue 陈悦 for providing material and clues for the research, and to Dr. Liu Kexi 刘柯希 for his help in collecting foreign literature, and last but not least, to Ms. Yu Yueyuan for her help in translating and revising this paper.

\section{References}

Bastid-Bruguière, Marianne. 1991. “Qingmo fu Ou de liuxuesheng men: Fuzhou Chuanzheng Ju yinjin jindai jishu de qianqianhouhou” 清末赴欧的留学生们一一福州船政局引进近代技术的前 前后后 [Students Who Went to Europe for Further Study in the Late Qing: The Whole Story of How the Foochow Navy Yard Imported Modern Technology]. In Xinhai Geming shi congkan 辛 亥革命史丛刊 [History of the Xinhai Revolution], series 8, edited by the Research Society of Central and Southern China on Xinhai Revolution and the Wuchang Xinhai Revolution Research Center. Beijing: Zhonghua Book Company.

Belhoste, Bruno. 2003. La Formation d'une technocratie: L'École polytechnique et ses élèves de la 
Révolution au Second Empire. Paris: Belin.

Bertin, Louis E. 1896. Chaudières marines: cours de machines à vapeur professé à l'École d'application du génie maritime. Paris: E. Bernard et Cie.

Brassey, Thomas Allnutt. 1888. "Recent Naval Administration." In Naval Annual, 1887. Portsmouth: J. Griffin \& Co.

Chen, Gideon 陳其田. 1938. Tso Tsung T'ang: Pioneer Promoter of the Modern Dockyard and the Woollen Mill in China. Peking: Yenching University.

Chen, Yue 陈悦. 2011. Jindai guozao jianchuan zhi 近代国造舰船志 [Chronicle of Warships Built in China in Modern Times]. Jinan: Shandong Pictorial Publishing House.

Chen, Yue. 2017. Chuanzheng shi 船政史 [History of the Foochow Navy Yard]. Fuzhou: Fujian People's Publishing House.

Ding, Richang 丁日昌. [1876] 2006. “Dishiqihao 'Yixin' lunchuan xiashui pian” 第十七號 “㙯 新” 輪船下水片 [Memorial to the Throne: The Seventeenth Ship “Yixin” Was Launched]. In Chuanzheng wenhua yanjiu: Chuanzheng zouyi huibian dianjiao ji 船政文化研究——船政奏议汇编 点校辑 [Research on the Chuanzheng Culture: A Collated Collection of Memorials to the Throne on Matters Related to the Foochow Navy Yard], edited by Zhang Zuoxing 张作兴, 122-123. Fuzhou: Sea Tide Photography Publishing House.

Feimo, Wenyu 費莫 - 文显. [1871] 2006a. “Diqi, diba lianghao lunchuan xiashui qingxing zhe” 第 七、第八兩號輪船下水情形折 [Memorial to the Throne: An Introduction of the Situation of the Launch of the Seventh and the Eighth Ship]. In Chuanzheng wenhua yanjiu: Chuanzheng zouyi huibian dianjiao ji, edited by Zhang Zuoxing, 62. Fuzhou: Sea Tide Photography Publishing House.

Feimo, Wenyu. [1871] 2006b. “Diwuhao lunchuan xiashui bing zizhi qilu, lunji gaocheng diqibahao liangchuan zhizao qingxing zhe” 第五號輪船下水並自製汽爐、輪機告成，第七、八 號兩船製造情形折 [Memorial to the Throne: The Fifth Ship Launched, Its Boiler and Steam Engine Completed, and an Introduction of the Current Situation of the Seventh and the Eighth Ships]. In Chuanzheng wenhua yanjiu: Chuanzheng zouyi huibian dianjiao ji, edited by Zhang Zuoxing, 60. Fuzhou: Sea Tide Photography Publishing House.

Gardiner, Robert, ed. 1979. Conway's All the World's Fighting Ships, 1860-1905. London: Conway Maritime Press.

Giquel, Prosper. 1874. L'Arsenal de Fou-Tchéou: ses résultats. Shanghai: Imprimerie A. H. de Carvalho.

Guo, Songtao 郭嵩壽. [1878] 1984a. “Guangxu sinian qiyue shijiu ri” 光緒四年七月十九日 [The Nineteenth Day of the Seventh Month in the Fourth Year of Emperor Guangxu's Reign (Lunar Calendar)]. In Lundun yu Bali riji 伦敦与巴黎日记 [Diaries in London and Paris]. Changsha: Yuelu Press.

Guo, Songtao. [1878] 1984b. “Guangxu sinian wuyue chuer ri” 光緒四年五月初二日 [The Second Day of the Fifth Month in the Fourth Year of Emperor Guangxu's Reign (Lunar Calendar)]. In Lundun yu Bali riji. Changsha: Yuelu Press.

Guo, Songtao. [1878] 1984c. “Guangxu sinian wuyue chuqi ri” 光緒四年五月初七日 [The Seventh Day of the Fifth Month in the Fourth Year of Emperor Guangxu's Reign (Lunar Calendar)]. In Lundun yu Bali riji. Changsha: Yuelu Press.

Hauser, Alphonse. 1886. Cours de construction navale: professé à l'École d'application du génie maritime. Paris: E. Bernard et Cie. 
Hazen, William Babcock. 1872. The School and the Army in Germany and France. New York: Harper \& Brothers.

Hitara, Yulu 喜塔臘 - 裕祿. [1897] 2006a. “Tiaoqu shengtu rutang yiye bing ding nianxian, kecheng pian” 挑取生徒入堂肄業並定年限、課程片 [Memorial to the Throne: Students Selected to the School and the Term of Study and the Courses Decided]. In Chuanzheng wenhua yanjiu: Chuanzheng zouyi huibian dianjiao ji, edited by Zhang Zuoxing, 470-471. Fuzhou: Sea Tide Photography Publishing House.

Hitara, Yulu. [1897] 2006b. “Xuanpai disijie chuyang yiye xuesheng, hegu yongkuan bing pai jiandu daiwang zhe” 選派第四屆出洋肄業學生, 核估用款並派監督帶往折 [Memorial to the Throne: The Fourth Group of Students to Be Sent Abroad for Further Study Were Selected, the Budget Was Made, and the Supervisor Was Commissioned to Take the Money There]. In Chuanzheng wenhua yanjiu: Chuanzheng zouyi huibian dianjiao ji, edited by Zhang Zuoxing, 473478. Fuzhou: Sea Tide Photography Publishing House.

Institute of Modern History, Academia Sinica. 1957. Fuzhou chuanchang (yi) 福州船廠（一） [The Foochow Navy Yard, vol. 1]. In Haifang dang yi 海防档 • 乙 [Archives on Coastal Defense, Part Two]. Taipei: Institute of Modern History, Academia Sinica.

Leibo, Steven A. 1982. A French Adviser to Imperial China: The Dilemma of Prosper Giquel. PhD diss., Washington State University.

Li, Hongzhang 李鴻章. [1876] 2008. “Fu Wu Chunfan jingqin” 復吳春帆京卿 [Reply to Officer Wu Zancheng]. In Li Hongzhang quanji 李鸿章全集 [Complete Collection of Li Hongzhang's Writing], vol. 31, edited by Gu Tinglong 顾廷龙 and Dai Yi 戴逸. Hefei: Anhui Education Press.

Li, Hongzhang. [1880] 1961. "Guangxu liunian sanyue shiliuri Zhili Zongdu Li Hongzhang zou" 光緒六年三月十六日直隸總督李鴻章奏 [Memorial to the Throne Written by Li Hongzhang, Governor-General of Zhili, on April 24, 1880]. In Zhongguo jindaishi ziliao congkan: Yangwu Yundong 中国近代史资料丛刊 - 洋务运动 [Book Series of Materials on Modern History in China: The Westernization], edited by Associations of Chinese Historians, vol. 5:239-241. Shanghai: Shanghai People's Publishing House.

Li, Zhaotang 黎兆棠. [1881] 2006. “Xunhai kuaichuan kaigong riqi bing chouban yiqie qingxing zhe” 巡海快船開工日期並籌辦一切情形折 [Memorial to the Throne: The Date When Construction of the Cruiser Commenced, and All the Conditions of This Construction]. In Chuanzheng wenhua yanjiu: Chuanzheng zouyi huibian dianjiao ji, edited by Zhang Zuoxing, 191. Fuzhou: Sea Tide Photography Publishing House.

Li, Zhaotang. [1883] 2006. “Chuangzhi xunhai kuaichuan xiashui bing chen changgong qingxing zhe” 創制巡海快船下水並陳廠工情形折 [Memorial to the Throne: The Cruiser that We Built was Launched, and a Report on the Work in the Shipyard]. In Chuanzheng wenhua yanjiu: Chuanzheng zouyi huibian dianjiao ji, edited by Zhang Zuoxing, 200-202. Fuzhou: Sea Tide Photography Publishing House.

Ma, Yau-Woon 馬幼垣. 2013. “Beiyang Haijun 'Pingyuan' jian kaoshi” 北洋海军 “平远” 舰考释 [Research on and Explanation of Pingyuan in the Peiyang Squadron]. In Jinghai chengjiang: Zhongguo jindai haijun shishi xinquan (shangce) 靖海澄疆: 中国近代海军史事新诠（上册） [A New Interpretation of the History of the Modern Chinese Navy, vol. 1]. Beijing: Zhonghua Book Company.

Pei, Yinsen 裴荫森. [1885] 2006a. “Kenqing bokuan shizao gangjia bingchuan zhe” 懇請撥款試造 
鋼甲兵船折 [Memorial to the Throne: Pleading for Appropriation for the Attempt to Build Ironclads]. In Chuanzheng wenhua yanjiu: Chuanzheng zouyi huibian dianjiao ji, edited by Zhang Zuoxing, 271-273. Fuzhou: Sea Tide Photography Publishing House.

Pei, Yinsen. [1885] 2006b. “Yang jiaoxi dao gong, tiangai xuetang yangfang pian” 洋教習到工, 添蓋學堂洋房片 [Memorial to the Throne: The Foreign Instructor Arrived, and Buildings were Added to the School]. In Chuanzheng wenhua yanjiu: Chuanzheng zouyi huibian dianjiao ji, edited by Zhang Zuoxing, 278-279. Fuzhou: Sea Tide Photography Publishing House.

Pei, Yinsen [1886] 2006. “Changzao dierhao kuaichuan gongjun xiashui zhe” 廠造第二號快船工竣 下水折 [Memorial to the Throne: The Second Cruiser Built by the Foochow Navy Yard Has Been Completed and Launched]. In Chuanzheng wenhua yanjiu: Chuanzheng zouyi huibian dianjiao ji, edited by Zhang Zuoxing, 295-296. Fuzhou: Sea Tide Photography Publishing House.

Pei, Yinsen. [1888] 2006. "Shuangji gangiia bingchuan xiashui bingchen xianzai changwu qingxing zhe" 雙機鋼甲兵船下水並陳現在廠務情形折 [Memorial to the Throne: The Iron-Clad Warship with Double Steam Engines Was Launched, and a Report on Current Situation in the Shipyard]. In Chuanzheng wenhua yanjiu: Chuanzheng zouyi huibian dianjiao ji, edited by Zhang Zuoxing, 364-365. Fuzhou: Sea Tide Photography Publishing House.

Pei, Yinsen. [1890] 2006. "Sanjie chuyang xuesheng xuecheng bing xiangban yiye geyuan chuli, fenbie jiangli zhe” 三屆出洋學生學成並襄辦肄業各員出力, 分別獎勵折 [Memorial to the Throne: The Third Group of Students That Were Sent Abroad Have Finished Their Studies. The Students and Those Who Had Helped in This Matter Received Their Reward]. In Chuanzheng wenhua yanjiu: Chuanzheng zouyi huibian dianjiao ji, edited by Zhang Zuoxing, 402403. Fuzhou: Sea Tide Photography Publishing House.

Pong, David. 1994. Shen Pao-chen and China's Modernization in the Nineteenth Century. Cambridge: Cambridge University Press.

Ren, Yanxiang 任燕翔. 2013. “Jiawu zhanqian de tiejiajian renzhi jiqi dui haijun jianchuan zhuangbei caigou de yingxiang” 甲午战前的铁甲舰认知及其对海军舰船装备采购的影响 [Perceptions of the Ironclad Ships and Its Influence on Naval Ships Procurement before the Sino-Japanese War of 1894-1895]. Junshi lishi 军事历史 [Military History] (4): 34.

Roberts, Stephen S. 1974. “The Imperial Chinese Steam Navy, 1862-1895." Warship International 11 (1): 27.

Ropp, Theodore. 1987. The Development of a Modern Navy: French Naval Policy 1871-1904. Annapolis, Maryland: Naval Institute Press.

Sennett, Richard, and Oram, Henry J. 1899. The Marine Steam Engine (The Fourth Edition). London: Longmans, Green \& Co.

Shen, Baozhen 沈葆楨. [1867] 2006. "Chakan Fuzhou haikou ji chuanwu dagai qingxing zhe" 察 看福州海口及船塢大概情形折 [Memorial to the Throne: Report on Inspecting the General Situation of Estuary at Fuzhou and the Dockyard]. In Chuanzheng wenhua yanjiu: Chuanzheng zouyi huibian dianjiao ji, edited by Zhang Zuoxing, 24. Fuzhou: Sea Tide Photography Publishing House.

Shen, Baozhen. [1868] 2006. “Jiqi daogong yiqi bing chuanchang xianzai qingxing zhe” 機器到工 已齊並船廠現在情形折 [Memorial to the Throne: All the Machinery Have Arrived, and a Report on the Current Situation of the Navy Yard]. In Chuanzheng wenhua yanjiu: Chuanzheng zouyi huibian dianjiao ji, edited by Zhang Zuoxing, 41. Fuzhou: Sea Tide Photography 
Publishing House.

Shen, Baozhen. [1869] 2006a. “Diyihao lunchuan fu Jin zhe” 第一號轮船赴津折 [Memorial to the Throne: The First Ship Was Sent to Tianjin]. In Chuanzheng wenhua yanjiu: Chuanzheng zouyi huibian dianjiao ji, edited by Zhang Zuoxing, 50. Fuzhou: Sea Tide Photography Publishing House. Shen, Baozhen. [1869] 2006b. “Xianmu luxu daogong, diyihao chuanshen gaocheng zhe” 暹木陸 續到工, 第一號船身告成折 [Memorial to the Throne: Timber from Siam Successively Arrived at the Navy Yard, and the Hull of the First Ship Has Been Completed]. In Chuanzheng wenhua yanjiu: Chuanzheng zouyi huibian dianjiao ji, edited by Zhang Zuoxing, 46. Fuzhou: Sea Tide Photography Publishing House.

Shen, Baozhen. [1874] 2006. “Waiyang yuan jiang zunyue qiansan zhe” 外洋員匠遵約遣散折 [Memorial to the Throne: The Foreign Employees and Craftsmen Were Dismissed According to the Contract]. In Chuanzheng wenhua yanjiu: Chuanzheng zouyi huibian dianjiao ji, edited by Zhang Zuoxing, 79. Fuzhou: Sea Tide Photography Publishing House.

Shen, Baozhen. [1875] 2006. “Baoming yitong sui Ri Jiandu chuyang pian” 報明藝童隨日監督出 洋片 [Memorial to the Throne: Report on That Apprentices Will Go Abroad with Giquel the Supervisor]. In Chuanzheng wenhua yanjiu: Chuanzheng zouyi huibian dianjiao ji, edited by Zhang Zuoxing, 103. Fuzhou: Sea Tide Photography Publishing House.

Shen, Baozhen. 2017. Shen Wensu gong zhengshu 沈文肃公政书 [A Collection of Mr. Shen Baozhen's Memorials to the Throne]. Beijing: Blossom Press.

Soley, James Russell. 1880. Report on Foreign Systems of Naval Education. Washington: US Government Printing Office.

Sun, Zhanyuan 孙占元. 1995. Zuo Zongtang pingzhuan 左宗棠评传 [A Critical Biography of Zuo Zongtang]. Nanjing: Nanjing University Press.

Wang, Xinzhong 王信忠. 1932. “Fuzhou Chuanchang zhi yange” 福州船廠之沿革 [The Evolution of the Foochow Navy Yard]. Qinghua xuebao 清华学报 [Journal of Tsinghua University] 8 (1): 1-57.

Xu, Jingcheng 许景澄. 1885a. Waiguo shichuan tubiao 外国师船图表 [Pictures and Charts of Foreign Warships], volume 3: France. Printed by the Embassy in Berlin.

$\mathrm{Xu}$, Jingcheng. 1885b. Waiguo shichuan tubiao, volume 5: Germany. Printed by the Embassy in Berlin.

Zeng, Guofan 曾國藩. [1860] 1985. “Fuchen yangren zhujiao ji caimi yun Jin zhe” 復陳洋人助剿 及采米運津折 [Memorial to the Throne: The Second Report on Foreign Soldiers' Assistance in Suppressing Rebellions, and Also Purchasing Rice to Transport to Tianjin]. In Zeng Guofan Quanji: Zougao 曾国藩全集・奏稿 [Complete Collection of Zeng Guofan's Writing: Memorials], 370. Changsha: Yuelu Press.

Zhang, Baichun 张柏春, Tian Miao 田沝, and Zhang Jiuchun 张久春. 2017. Keji geming yu Zhongguo xiandaihua 科技革命与中国现代化 [The Revolution in Science and Technology and China's Modernization]. Jinan: Shandong Education Press.

Zuo, Zongtang 左宗棠. [1866] 1986. “Ni gou jiqi gu yangjiang shizao lunchuan xian chen dagai qingxing zhe” 擬購機器雇洋匠試造輪船先陳大概情形折 [Memorial to the Throne: A Brief Introduction before Purchasing Machinery and Hiring Foreign Craftsmen to Attempt to Build Ships]. In Zuo Zongtang quanji 左宗常全集 [Complete Collection of Zuo Zongtang's Writing], vol. 4:2843-2854. Shanghai: Shanghai Book Store. 